Maurer School of Law: Indiana University

Digital Repository @ Maurer Law

Articles by Maurer Faculty

Faculty Scholarship

2021

The Fraud Triangle and Tax Evasion

Leandra Lederman

Follow this and additional works at: https://www.repository.law.indiana.edu/facpub

Part of the Tax Law Commons

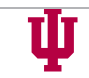

LAW LIBRARY

INDIANA UNIVERSITY

Maurer School of Lav
Bloomington 


\title{
The Fraud Triangle and Tax Evasion
}

\author{
Leandra Lederman*
}

\begin{abstract}
The "fraud triangle"-a theory of why people commit fraud -is the preeminent framework for analyzing fraud in the accounting literature. It developed out of studies of fraudsters, including inmates convicted of embezzlement. The three components of the fraud triangle are (I) an incentive or pressure (usually financial); (2) opportunity; and (3) rationalization.
\end{abstract}

There is a separate, extensive legal literature on tax compliance and evasion. The fraud triangle is largely absent from this legal literature, although tax evasion is a type of fraud. This Article rectifies that oversight, analyzing how using the fraud triangle as a lens can inform the legal literature on tax compliance. In addition, the Article argues that the fraud triangle can provide a conceptual frame that provides a place for two distinct types of tax compliance theories discussed in the legal literature: the traditional deterrence model and certain behavioral theories.

I. INTRODUCTION 1154

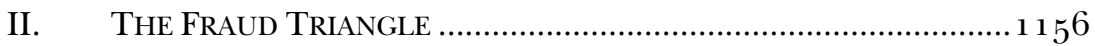

A. THE FRAUD TRIANGLE'S EMBEZZLEMENT ORIGINS.................. 1156

1. Donald Cressey's Work on Embezzlement................11 $15^{8}$

2. Critiques of Cressey's Work, and Subsequent Studies of Embezzlement ......................................... 1162

B. "FUN WHILE IT LASTED": THE ROLE OF EXPERIENTIAL

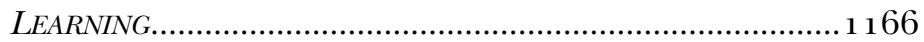

III. MiSCONCEPTIONS ABOUT THE FRAUd TRIANGLE ....................... 1169

A. THE SOURCE OF THE FACTORS ........................................... 1169

* William W. Oliver Professor of Tax Law, Indiana University Maurer School of Law. The author is grateful for helpful discussions with and comments from Alice Abreu, Leslie Book, Brian Broughman, Jonathan Choi, Charlotte Crane, Rita de la Feria, Ana Paula Dourado, Tina EhrkeRabel, Hilary Escajeda, Cliff Fleming, David Gamage, Christine Kim, Roberta Mann, Gregg Polsky, Tracey Roberts, Gladriel Shobe, and workshop participants at the following places: Brigham Young University, the Critical Tax Conference hosted by the University of Florida Levin College of Law, a National Tax Association meeting, the University of Graz, the University of Leeds, and the University of Lisbon. Sandra Francisco, Derrick Hou, Sarah Taylor, and Thibault Vieilledent provided helpful research assistance. 

B. THE FACTORS' PATH FROM EMBEZZLEMENT TO FRAUD .1173
C. WHO COINED THE "FRAUD TRIANGLE" NAME? 1180

IV. APPLying THE Fraud TRIANGLE TO TAX EVASION 1182
A. FinANCIAL PRESSURE OR INCENTIVE 1184
B. PERCEIVED OPPORTUNITY TO EVADE 1188
C. RATIONALIZATION 1190

V. Potential Implications for TAX COMPLiAnCE MOdELS....... 1193

A. THE DETERRENCE MODEL AND THE FraUd TRIANGLE ............. 1195

1. The Fraud Triangle's "Incentive or Pressure" Prong.... 1195

2. The Fraud Triangle's "Opportunity" Prong............... 1197

B. BEHAVIORAL APPROACHES TO TAX COMPLIANCE AND THE FRAUD TRIANGLE'S "RATIONALIZATION" PRONG .............. 1200

1. Norms of Compliance or Noncompliance ................ 1200

2. Taxpayer Views of Government ............................. 1202

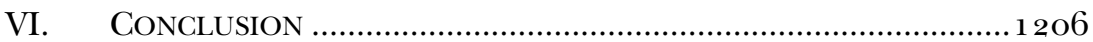

\section{INTRODUCTION}

Every tax system faces the prospect of evasion, forcing governments worldwide to grapple with the question of how to increase tax compliance. There is an extensive set of literatures on this issue spanning multiple fields, including both law and economics. The traditional economic model considers tax evasion a type of gamble. ${ }^{1}$ The legal literature frequently references that model and analyzes deterrence. ${ }^{2}$ In recent years, tax compliance scholarship has also considered behavioral explanations for compliance. ${ }^{3}$

1. See Michael G. Allingham \& Agnar Sandmo, Income Tax Evasion: A Theoretical Analysis, 1 J. PUB. ECON. 323, 324 (1972) ("The tax declaration decision is a decision under uncertainty. ... The taxpayer has the choice between two main strategies: (1) He may declare his actual income. (2) He may declare less than his actual income.”).

2. For recent examples, see Kathleen DeLaney Thomas, The Psychic Cost of Tax Evasion, $5^{6}$ B.C. L. REV. $617,622(2015)$ ("Standard deterrence theory, as applied to tax compliance, assumes that taxpayers are rational actors seeking to maximize their expected utility."); Leandra Lederman, Does Enforcement Reduce Voluntary Tax Compliance?, 2018 BYU L. REV. 623, $642-55$ (discussing the deterrence model); and Adam B. Thimmesch, Testing the Models of Tax Compliance: The Use-Tax Experiment, 2015 UTAH L. REV. 1083, 1084 ("Traditional economic or deterrence theories assert that the decision to comply depends on a cost-benefit or expected-utility analysis.").

3. See, e.g., Bruno S. Frey, Deterrence and Tax Morale in the European Union, 11 EUR. REV. $38_{5}$, 389 (2003) ("[The article] seeks to demonstrate that intrinsic motivation in the form of "tax morale' is of substantial importance in explaining tax paying behaviour.”); Dan M. Kahan, Signaling or Reciprocating? A Response to Eric Posner's Law and Social Norms, 36 U. RICH. L. REV. 367,380 (2002) ("The reciprocity theory not only furnishes a convincing explanation for the phenomenon of tax evasion; it also suggests a novel theory for combating it: the promotion 
There is also a separate accounting literature on fraud. A central concept in the accounting literature is the fraud triangle, which has been called " $[\mathrm{t}]$ he dominant framework relating to fraud ... [,] embedded in professional auditing standards around the world including the USA, Australia and international audit standards." 4 The fraud triangle is a theory of why people commit fraud.5 The "triangle" aspect of the fraud triangle reflects the fact that the theory contains three factors. ${ }^{6}$ The fraud triangle has been applied to a wide range of malfeasance, including student plagiarism; the Volkswagen emissions scandal; and Bernie Madoff's Ponzi scheme.7

Despite the preeminent role the fraud triangle theory plays within the accounting literature on fraud, it is almost entirely absent from the extensive legal literature on tax compliance and evasion. ${ }^{8}$ This Article both fills the gap in the legal literature and resolves some inconsistencies in the applicable accounting literature.

This Article is as much about the fraud triangle as it is about tax evasion. Thus, the first two major Parts that follow this Introduction focus on the fraud triangle itself, while the remaining two address connections between the tax compliance literature and the fraud triangle. Part II begins with a discussion of the fascinating history and evolution of the fraud triangle. This Part also examines the role of experiential learning in the fraud triangle, using as an example the experiences of Hollywood producer and sports executive Bruce McNall, as described in his book, Fun While It Lasted. That is one of the Article's contributions to the fraud triangle literature.

Part III then focuses on the accounting literature on the fraud triangle. This Part analyzes and proposes resolutions to some confusion in that literature, including (1) the contested origins of the "fraud triangle" name, and (2) how the theory was extended from studies of embezzlement to other types of fraud.

Part IV of the Article turns to the tax context, exploring how each of the triangle's three factors can inform thinking about tax evasion. Part $\mathrm{V}$ then applies the fraud triangle framework to the tax compliance literature. A major

of trust."); Thimmesch, supra note 2, at 1095 ("One significant nonpecuniary model of tax compliance suggests a social-norm rationale for tax-compliance decisions.").

4. Clinton Free, Looking Through the Fraud Triangle: A Review and Call for New Directions, 23 MEDITARI ACCT. RSCH. 175, 177 (2015) (citations omitted).

5. See infra Section II.A.

6. See infra text accompanying notes 9-10.

7. See, e.g., Kenneth H. Ryesky, Part Time Soldiers: Deploying Adjunct Faculty in the War Against Student Plagiarism, 2007 BYU EDUC. \& L.J. 119, 144-46 (student plagiarism); Mandy Moody, Placing Volkswagen into the Fraud Triangle, FRAUD CONF. News (June 14, 2016), https:// www.fraudconferencenews.com/home/2016/6/14/placing-volkswagen-into-the-fraud-triangle [https://perma.cc/NEF4-Y2NB] (Volkswagen); Walter Pavlo, Bernard Madoff is the Fraud Triangle, FORBES (Mar. 1, 2011, 9:28 AM), https://www.forbes.com/sites/walterpavlo/2011/03/01/ bernard-madoff-is-the-fraud-triangle/\# 59 ea2f 346 cad [https://perma.cc/VW4L-BNHB] (Bernie Madoff); see also W. Steve Albrecht, Iconic Fraud Triangle Endures, FrAUD MAG., July-Aug. 2014, at 1, 7 (citing such examples as student cheating, exceeding a speed limit, and cheating on one's spouse).

8. See infra note 199 and accompanying text. 
contribution of this Article is that it argues that the fraud triangle can serve as a lens that helps bridge the leading theories of tax compliance: the deterrence model and behavioral approaches.

\section{The Fraud TRIANGLE}

The fraud triangle is a three-pronged theory of why some individuals commit occupational fraud. The triangle's three factors have evolved somewhat over the years, as discussed below.9 However, the current factors are generally understood to be those described in American Institute of Certified Public Accountants ("AICPA") and international auditing standards: "Fraud, whether fraudulent financial reporting or misappropriation of assets, involves incentive or pressure to commit fraud, a perceived opportunity to do so, and some rationalization of the act ...."1 ${ }^{\circ}$ The AICPA adopted these standards in the early 200os, in what was then called Statements on Auditing Standards ("SAS") No. 99. ${ }^{11}$ The International Auditing and Assurance Standards Board followed suit in International Standards on Auditing ("ISA") 240. ${ }^{12}$ Although the accounting standards do not specifically use the phrase "fraud triangle," they are understood to refer to it. ${ }^{13}$

\section{A. THE FRAUD TRIANGLE'S EMBEZZLEMENT ORIGINS}

The origins of the fraud triangle lie neither with the accounting profession nor in the twenty-first century. Instead, Donald Cressey's work on

9. See infra Sections II.A-.B.

10. Codification of Acct. Standards \& Procs., Clarified Statements on Auditing Standards, AU-C § 240.Aı (AM. INST. OF CERTIFIED PUB. ACCTS. 2020) (emphasis added); INT'L Auditing \& Assurance Standards Bd., InTERnAtional StANDARD ON Auditing 24o: The AUDitor's RESPONSIBILITIES RELATING TO FRAUd IN AN AUdit OF FinANCIAL STATEMENTS If A 1 (2009) [hereinafter ISA 240] (emphasis added).

11. Codification Of ACCT. Standards \& Procs., Statement on Auditing Standards No. 99, 17 (AM. INST. OF CERTIFIED PUB. ACCTS. 2002). SAS No. 99 was subsequently incorporated into AU section 316. See Pre-Clarity Statements on Auditing Standards, Am. InST. Of CERTIFIED PUB. ACCTS., https://www.aicpa.org/research/standards/auditattest/sas.html [https://perma.cc/ W66H-TWBZ]. AU section 316 has since been superseded by AU-C section 240. See AM. INST. OF Certified Pub. ACCTS., AU-C ExhiBIT A (2013), https://www.aicpa.org/content/dam/aicpa/ research/standards/auditattest/downloadabledocuments/au-c-exhibita.pdf [https://perma.cc/ C8PC-7FSW].

12. Auditor's Responsibility to Consider Fraud in an Audit of Financial Statements, INT'L AUDITING \& ASSURANCE STANDARDS BD. (Feb. 2004) [hereinafter Auditor's Responsibility], https:// www.iaasb.org/projects/auditors-responsibility-consider-fraud-audit-financial-statements [https:// perma.cc/ 4 BNF-SZBN] (discussing revisions to ISA 240 ).

13. See, e.g., Albrecht, supra note 7, at 6 (" $[\mathrm{I}] \mathrm{n}$ 2002, the Auditing Standards Board of the American Institute of Certified Public Accountants used the Fraud Triangle as a critical element of 'SAS 99: Consideration of Fraud."); Free, supra note 4, at 177 ("The dominant framework relating to fraud is the so-called 'fraud triangle,' which is embedded in professional auditing standards around the world including the USA (SAS No. 99), Australia (ASA 240) and international audit standards (ISA 240)." (citations omitted)); David T. Wolfe \& Dana R. Hermanson, The Fraud Diamond: Considering the Four Elements of Fraud, CPA J., Dec. 2004, at 38 , 38 ("This three-pronged framework, commonly known as the 'fraud triangle,' has . . . . been formally adopted by the auditing profession as part of SAS 99.”). 
embezzlement in the early $195^{\circ}$ os is generally credited as the origin of the theory, ${ }^{14}$ sometimes with Edwin Sutherland's work as its antecedent. ${ }^{15}$ Cressey developed three factors to explain why some individuals employed in positions of trust violate that trust by absconding with the entrusted funds, while others do not. ${ }^{16}$ Cressey's three factors were (1) a non-shareable pressure (generally financial); (2) a perceived opportunity to embezzle; and (3) rationalization of the planned violation. ${ }^{17}$

Cressey began this work as a Ph.D. student of Edwin Sutherland's at Indiana University. ${ }^{18}$ Sutherland, who "coined the term "white collar crime"" in a 1939 speech to the American Sociological Association, ${ }^{19}$ was seeking to overcome a common understanding of crime as committed overwhelmingly by members of the "lower class" 20 and thus "caused by poverty or by personal and social characteristics believed to be associated statistically with poverty." ${ }_{21}$ Sutherland argued that criminality was learned behavior, rather than due to personal characteristics. He called the process "differential association" because he argued that criminality depends on the frequency with which the

14. See, e.g., Rasha Kassem \& Andrew Higson, The New Fraud Triangle Model, 3 J. EMERGING TRENDS ECON. \& MGMT. SCIS. 191, 193 (2012) ("Cressey's fraud theory, normally known as the fraud triangle theory, was widely supported and used by audit professionals and standards' setters as a tool for detecting fraud."); Alexander Schuchter \& Michael Levi, The Fraud Triangle Revisited, 29 SEC. J. 107, 107 (2016) [hereinafter Schuchter \& Levi, Revisited] ("This article revisits the Fraud Triangle, an explanatory framework for financial fraud, developed by the American criminologist Donald Cressey.”).

Throughout this Article, the term "embezzlement" is not used in a strictly technical sense, but rather is used to refer to any illegal misappropriation of entrusted funds. Cf. infra note 30 (discussing how Donald Cressey addressed this issue).

15. See, e.g., Albrecht, supra note 7, at 1-2 ("Two individuals who probably deserve the most credit for the fraud [triangle] model are early criminology researchers Edwin Sutherland and Donald Cressey.”); Jack W. Dorminey, Arron Scott Fleming, Mary-Jo Kranacher \& Richard A. Riley, Jr., Beyond the Fraud Triangle: Enhancing Deterrence of Economic Crimes, CPA J., July 2010, at 17 , 18 [hereinafter Dorminey et al., Enhancing Deterrence] ("The concept of a fraud triangle dates back to the work of Edwin Sutherland, who coined the term white-collar crime, and Donald Cressey, who wrote Other People's Money.").

16. See Donald R. Cressey, Other People's Money: A Study in the Social Psychology of EMbeZzlement 12 (1953) [hereinafter CRESSEy, OTHER PEOPLE's MONEY].

17. Id. at 30 .

18. See Albrecht, supra note 7, at 2; Ronald L. Akers \& Ross L. Matsueda, Donald R. Cressey: An Intellectual Portrait of a Criminologist, 59 SOCIO. INQUIRY 423, 424 (1989) (discussing Cressey's dissertation).

19. Edwin H. Sutherland, White-Collar Criminality, 5 AM. SocIO. REV. 1, 3 (1940) [hereinafter Sutherland, White-Collar Criminality]; see Jérémy Morales, Yves Gendron \& Henri Guénin-Paracini, The Construction of the Risky Individual and Vigilant Organization: A Genealogy of the Fraud Triangle, 39 ACCT., ORGS. \& SOC'Y 1 70, 173 (2014).

20. Sutherland, White-Collar Criminality, supra note 19, at 1 ("The criminal statistics show unequivocally that crime, as popularly conceived and officially measured, has a high incidence in the lower class and a low incidence in the upper class; less than two percent of the persons committed to prisons in a year belong to the upper class.").

21. Id.; see also Morales et al., supra note 19, at 173 ("Sutherland showed that criminology greatly underestimated (or even obscured) the violations of law perpetrated by persons of the upper socioeconomic class." (citation omitted)). 
person associates with criminal or non-criminal behavior ${ }^{22}$-an argument that today would likely refer to the norms of the individual's community or workplace. ${ }^{23}$

\section{Donald Cressey's Work on Embezzlement}

Cressey argued that "Sutherland's position was confused by the fact that he studied corporations, rather than individual white-collar criminals." ${ }_{24}$ To address that concern, Cressey focused his doctoral research on individuals. ${ }^{25}$ He stated, "[i] t was my impression that embezzlers are white-collar criminals whose backgrounds are not likely to contain the social and personal pathologies which popular notions and traditional theory ascribe to criminals." ${ }^{26}$

In this research, which became a book, Cressey's "objective [was] to separate, on the basis of a causal process, the behavior of trusted persons who violate their trust from the behavior of nonviolators." 27 In other words, he sought an explanation for why "some persons in positions of financial trust violate that trust, whereas other persons, or even the same person at a different time, in identical or very similar positions do not so violate it." 28

22. See Sutherland, White-Collar Criminality, supra note 19, at 11 ("Whether a person becomes a criminal or not is determined largely by the comparative frequency and intimacy of his contacts with the two types of behavior.").

23. Cf. Cheryl Lero Jonson \& Gilbert Geis, Cressey, Donald R.: Embezzlement and White-Collar Crime, in 1 ENCYClOPEDIA OF CRIMINOLOGICAL THEORY 223, 228 (Francis T. Cullen \& Pamela Wilcox eds., 2010) ("Cressey especially applied Sutherland's differential association theory to the analysis and control of management fraud. He argued that management fraud could be explained through an understanding that people are exposed to definitions both favorable and unfavorable to the violation of law." (citations omitted)).

24. Donald R. Cressey, The Respectable Criminal, 3 CRIMINOLOGICA 13, 13 (1965) [hereinafter Cressey, Respectable Criminal].

25. Joseph T. Wells, Occupational Fraud and Abuse: How To Prevent and Detect ASSET Misappropriation, Corruption AND Fraudulent Statements 10 (1997). While a sociology graduate student at Indiana University, Cressey took a course from Jerome Hall at the law school, which was very unusual at the time. Donald R. Cressey, Dedication, Jerome Hall, $3^{2}$ HASTINGS L.J. 1379, 1384-85 (1981) [hereinafter Cressey, Jerome Hall].

26. Cressey, Respectable Criminal, supra note 24, at 13 .

Cressey noted that the trust-violation crimes he studied did not all constitute "white-collar crime" as defined by Sutherland:

As a class of crimes, trust violation cannot be considered as "white collar crime." Sutherland has defined that type of crime as violation of law by persons of respectability and high social status in the course of their occupations. . . While the crimes of trust violators are committed in the course of their occupations, many of the violators encountered cannot be considered as persons of high social status or as respected persons of the community.

Cressey, Other PeOPle's MONEy, supra note 16 , at 184 n.9 (citing EDWIN H. SUTHERLAND, White COLLAR CRIME 9 (1949)).

27. Donald R. Cressey, Why Do Trusted Persons Commit Fraud?: A Social-Psychological Study of Defalcators, $9^{2}$ J. ACCT. 576, 577 (1951) [hereinafter Cressey, Trusted Persons]. Gwynn Nettler reports that it was the "moral denigration of the embezzler that piqued Cressey and against which his hypothesis has been advanced." Gwynn Nettler, Embezzlement Without Problems, 14 BRIT. J. CRIMINOLOGY 7O, 72 (1974).

28. Cressey, Other PeOPle's MONEY, supra note 16, at 12 (emphasis added). 
Cressey conducted interviews with inmates in three penitentiaries (one each in California, Illinois, and Indiana), ${ }^{29}$ who, after apparently accepting a position of trust in good faith, had been convicted of embezzlement or a similar crime. $3^{\circ}$ Cressey's sample included a total of 133 men. ${ }^{11}$ Because Cressey was not interested in the career criminal or people who had accepted a position planning to embezzle, he excluded from his sample numerous inmates who had not accepted the position of trust in good faith. $3^{2}$

The method Cressey used was analytic induction, which "involves a researcher beginning with a set of postulates and then continually readjusting them so that they encompass all evidence that the data produce. Thus, if a negative case is found, the hypothesis is reformulated until all cases support the generalization." 33 Cressey states that his "formulation of hypotheses was guided entirely by the search for negative cases" to disprove the hypotheses. ${ }^{34}$ Using this methodology, Cressey rejected several hypotheses as not fitting all of the inmates he interviewed. 35 Ultimately, he phrased his summary as follows:

Trusted persons become trust violators when: (1) they conceive of themselves as having a financial problem which is non-shareable; (2) have the knowledge or awareness that this problem can be secretly resolved by violation of the position of financial trust; and (3) are able to apply to their own conduct in that situation a verbalization which enables them to adjust their conceptions of

29. Id. at 22-23. The interviews were conducted from 1949 to $195^{1}$. Id. Cressey's sample included both state and federal prisoners. See Cressey, Respectable Criminal, supra note 24, at 14 ("I was disturbed because my sample of embezzlers included very few bankers; this was because embezzlement is a federal offense and most of my interviews had been conducted in state prisons. So I spent a summer working in the United States Penitentiary in Terre Haute, Indiana.").

30. Cressey, Trusted Persons, supra note 27, at 578. Due to differences in legal definitions, Cressey's criteria for inclusion did not require that the crime constitute "embezzlement" under applicable law. Instead, the study focused on inmates who had "accepted a position of trust in good faith" and later "violated that trust by committing a crime." CRESSEY, OTHER PEOPLE'S MONEY, supra note 16 , at 20.

31. Id. at 25 ("The 73 inmates at Joliet, [Illinois;] the 21 at Chino[, California;] and the 39 at Terre Haute[, Indiana] whose cases met the criteria were interviewed frequently and at length.”). Thus, Cressey's subjects, unlike Svend Riemer's-discussed below-were not specifically selected on the basis of having raised or been considered for an insanity defense. See infra text accompanying notes 1 19-20 (discussing Riemer's case selection).

32. See CRESSEY, OTHER PEOPLE'S MONEY, supra note 16, at 23 (stating that he screened 503 inmates and "as expected, ... many cases did not meet the first criterion-acceptance of a position of trust in good faith"). Some scholars have referred to the type of criminal Cressey was focused on as the "accidental fraudster." See Jack Dorminey, A. Scott Fleming, Mary-Jo Kranacher \& Richard A. Riley, Jr., The Evolution of Fraud Theory, 27 Issues ACCT. EDUC. 555, 565-66 (2012) [hereinafter Dorminey et al., Evolution of Fraud Theory]. This contrasts with what may be termed a "predator." See id. at $5^{6} 5^{-68}$.

33. Jonson \& Geis, supra note 23 , at 225.

34. Cressey, Other PeOPle's Money, supra note 16 , at 17.

35. Cressey, Trusted Persons, supra note 27 , at 578 . 
themselves as trusted persons with their conceptions of themselves as users of the entrusted funds or property. $3^{6}$

Thus, Cressey found three factors common to individuals who became embezzlers or similar trust violators. 37 These three factors are typically credited with providing the origin of the fraud triangle theory..$^{8}$ Cressey's first factor, a non-shareable financial pressure, could involve something embarrassing to the individual, such as a gambling debt 39 or failure of his business. $4^{\circ}$ Cressey considered non-shareability-the subjective inability to tell intimates, such as the individual's wife ${ }^{1}$ - critical to embezzlement. $4^{2}$ Of Cressey's three factors, this one has undergone the most change over the years, as discussed below.

Cressey's second factor involves the perceived opportunity to commit the trust violation. 43 Cressey argued that opportunity involved not just holding the position of trust but also perceiving the opportunity to convert entrusted funds for one's own use. 44 The trust violator may also use technical skills to

36. Id. at $577-78$.

37. Cressey found that all three factors he identified as common to the cases were necessary for the crime to occur. Cressey, Other PeOple's MONey, supra note 16, at 31 ("The entire process must be present.").

38. See supra notes $14^{-1} 7$ and accompanying text.

39. Cressey, Trusted Persons, supra note 27 , at 578 .

40. Id. at $579-80$.

41. See Cressey, Other PeOple's Money, supra note 16, at 28 ("[T] he specific hypothesis here was unknowingly suggested by a prisoner who stated that he believed that no embezzlement would ever occur if the trusted person always told his wife and family about his financial problems, no matter what the consequences."); Donald R. Cressey, The Criminal Violation of Financial Trust, 15 AM. SOCIO. REV. 738, $74^{2}$ n.13 (1950) [hereinafter Cressey, Criminal Violation] ("None of [the trust violators], of course, used the words 'non-shareable problem,' but many of them stated that they were 'ashamed' to tell anyone of a certain situation or that they had 'too much false pride' to get help from others.").

42. See Cressey, Other People's Money, supra note 16, at 34, 75; Cressey, Respectable Criminal, supra note 24 , at 15 ("Wherever a company program solves a financial problem, or makes it shareable, embezzlement will not occur."). However, "[t]hirty years after his original research, Cressey concluded that while the unshareable problem was important, it was 'not critical,' and it was the neutralization of the criminal nature of the behavior that was his most salient finding." Gary S. Green, White-Collar Crime and the Study of Embezzlement, 525 AnNALS AM. ACAD. POL. \& SOC. SCI. 95, 102 (1993).

At least one of the cases Cressey considered seems to undermine the non-shareability factor. Cressey quotes Case 237, which was "[f]rom the files of a District Attorney's Office," as involving a banker whose "wife needed some medical attention of an unethical nature, and through a friend he got in touch with a doctor in X who" later demanded money from him. CRESSEY, OTHER PEOPLE'S MONEY, supra note 16 , at 71 . In this case, the embezzler's wife was aware of at least the source of the financial pressure-the "unethical" medical service. Cf. $i d$. at $5^{\mathrm{O}}$ (quoting Case 99 as stating, "My wife only knew about it when I got about \$3,ooo short.").

43. See id. at 77 .

44. $I d$. 
identify the opportunity 45 that "opens the doorway to fraud." ${ }^{6}{ }^{6}$ For example, in Cressey's Case 47, an accountant stated:

I learned all of it in school and in my ordinary accounting experience. In school they teach you in your advanced years how to detect embezzlements, and you sort of absorb it. . . I did not use any techniques which any ordinary accountant in my position could not have used . . . .47

The third Cressey factor is rationalization of the behavior as somehow acceptable ${ }^{8}$ - a mental verbalization of the planned act as not really criminal or morally wrong. 49 Cressey stated that the rationalizing thought process of the eventual trust violator occurred before the trust violation, allowing it to occur. $5^{\circ}$ Rationalization serves the psychological purpose of minimizing the cognitive dissonance between thinking of oneself as honest and committing a dishonest act. $5^{1}$

Cressey further argued that " $[\mathrm{e}]$ ach trusted person does not invent a new rationalization for his violation of trust, but instead he applies to his own situation a verbalization which has been made available to him by virtue of his having come into contact with a culture in which such verbalizations are

45. Id. at $78-79,85$.

46. Wolfe \& Hermanson, supra note 13, at 38. Wolfe and Hermanson coined the term "fraud diamond" by adding the fourth factor of "capability" to the fraud triangle framework. See $i d$. at $38-4$ o. They state, in part:

Opportunity opens the doorway to fraud, and incentive and rationalization can draw the person toward it. But the person must have the capability to recognize the open doorway as an opportunity and to take advantage of it by walking through, not just once, but time and time again. Accordingly, the critical question is, "Who could turn an opportunity for fraud into reality?"

Id. at $38-39$.

As the discussion in the text illustrates, Cressey's use of the term "perceived opportunity" seems to include the skills necessary to exploit the opportunity. However, Wolfe and Hermanson seem focused on somewhat different things than Cressey was. Their focus, though overlapping with Cressey's, seems focused more on the repeated fraudster taking advantage of a perceived opportunity "not just once, but time and time again," than on what brings a previously honest person to embezzle for the first time. Id. at 39. Wolfe and Hermanson also describe "capability" as involving attributes of the fraudster that include not only the knowledge and intelligence necessary to carry out the fraud, but also the skills needed to avoid detection. Id. at 4o ("[A] successful fraudster lies effectively and consistently. To avoid detection, she must look auditors, investors, and others right in the eye and lie convincingly. She also possesses the skill to keep track of the lies, so that the overall story remains consistent.").

47. Cressey, Other PeOPle's Money, supra note 16 , at 82.

48. Id. at 93 .

49. See Cressey, Respectable Criminal, supra note 24 , at 15 .

5o. Cressey, Other People's Money, supra note 16, at 94 ("In the cases of trust violation encountered [,] significant rationalizations were always present before the criminal act took place, or at least at the time it took place, and, in fact, after the act had taken place[,] the rationalization often was abandoned.").

51. Sridhar Ramamoorti, The Psychology and Sociology of Fraud: Integrating the Behavioral Sciences Component into Fraud and Forensic Accounting Curricula, 23 ISSUES ACCT. EDUC. 521,525 (2008). 
present." $5^{2}$ This is reminiscent of the view of his mentor, Edwin Sutherland, that criminality is learned, rather than inherent.53

In searching for negative cases, Cressey stated that he examined the cases of the 133 men he interviewed, an additional approximately 200 case files "collected by E. H. Sutherland in the 1930's," 54 and other cases that Cressey found in the literature. He found that all cases he examined fit the three criteria or, if incomplete for his purposes, did not contain information inconsistent with those criteria.55 Cressey quotes from multiple case files to provide examples of each of the three criteria. $5^{6}$

\section{Critiques of Cressey's Work, and Subsequent Studies of Embezzlement}

Cressey's approach has the virtue of developing a succinct theory about why otherwise (presumably) honest individuals embezzle. However, it suffers from some deficiencies, particularly when extended beyond the population that Cressey studied. First, the analytic-induction methodology is itself an issue. Most notably, it lacks predictive power, serving only to describe the cases

\footnotetext{
52. CRESSEY, Other PEOPLE's MONEY, supra note 16 , at 137.

53. See supra text accompanying notes 22-23. Gary Green explains:
}

Cressey initially attempted to ascertain whether differential association explained embezzlement. The effort was understandable because Sutherland, his mentor, had labeled embezzlement a "white-collar crime" and had insisted that differential association was the most plausible explanation for all white-collar crime. While Cressey abandoned differential association early in his study as a root cause of embezzlement, he did report that his findings provided indirect support for the theory.

Green, supra note 42, at 103 (footnotes omitted); see also Donald R. Cressey, Application and Verification of the Differential Association Theory, 43 J. CRIM. L., CRIMINOLOGy \& POLICE SCI. 43, $5^{1}$ (1952) ("While the general contention of the differential association theory, that criminality is learned, cannot be disputed, the more specific idea that criminality and non-criminality depend upon a ratio of contacts with criminal and anti-criminal behavior patterns is open to question in cases of crimes involving violation of financial trust.").

54. Cressey, Other People's Money, supra note 16, at 3o. Few background details are provided about these cases. See Marshall B. Clinard, Book Review, 19 AM. SocIO. REV. 362, 362 (1954) (reviewing CRessey, OTHER PEOPle’s Money, supra note 16) (“[E]xactly how he used [Sutherland's] material and what information was available is not clear.”). Cressey does state in a footnote in his book that "[c]ases numbered 1 to 200 were collected by the writer, cases numbered 201 to 300 were collected by E. H. Sutherland in the 1930 's, and cases numbered 301 to 4 Oo are from other sources." CRESSEY, OTHER PEOPLE'S MONEY, supra note 16, at 170 n.3. These numbers are oddly round and do not seem to correspond to other figures in the book. That is, Cressey states in the text of the book that his interview sample consisted of 133 inmates -not 200-and that Sutherland had collected approximately 200 cases-not 10o. See id. at 25, 30.

55. Id. at 3o. Some of the cases Cressey did not collect himself lacked "crucial information" relating to Cressey's hypothesis. $I d$.

56. See, e.g., $i d$. at 37 (quoting from multiple case files relating to a non-shareable problem); $i d$. at 81 (quoting from two case files relating to opportunity on just that page); $i d$. at 103 (quoting from a case file relating to the "borrowing" rationalization). 
that have already been identified, 57 as Cressey recognized. $5^{8}$ Also, because Cressey did not "us[e] the more straightforward method of strict hypothesis testing[,] Cressey may well have forced his interpretations to fit his theme." 59 In addition, Cressey did not interview trusted individuals who were not known to have committed a trust violation, to see if they shared the three factors, ${ }^{6}$ so his study was not designed to have a control group. Instead, Cressey considered " $[\mathrm{e}]$ ach trust violator [as] his own 'control' since each of them at a prior time had been a non-violator." 61

Second, the interview methodology means that Cressey relied on the inmates' recollection of past events. It is possible that their recollections regarding the order of events was incorrect or distorted, perhaps in a systematic way. For example, some inmates may not have admitted to Cressey that they had also embezzled at previous times. Similarly, some inmates may state that they could not share the quandary with others as a post hoc justification of why they did not solve the problem using legitimate means. In other words, it is possible that, at the time of the financial pressure, the subject did not regard the problem as non-shareable, but rather came up with a solution (embezzlement) that was non-shareable. ${ }^{62}$ In addition, Cressey's argument that rationalization occurred before rather than after the offense

57. Jonson \& Geis, supra note 23, at 225 ("[Analytic induction] contains a major shortcoming from a scientific viewpoint in that it is not possible to use it for predictive purposes."); see also id. ("The death rite for analytic induction was pronounced by John Laub and Robert Sampson in 1991: "No empirical research today is guided by the theory."); Robert Schafer, Book Review, 3 INT'L REV. MOD. SOCIO. 114, 116 (1973) (reviewing Cressey, OTHER PEOPLE'S MONEY, supra note 16) ("In effect, the theory is limited to a post factum explanation of behavior. The reason for this lack of predictive capacity is that there is no basis for determining beforehand if the conditions specified as necessary for embezzlement will exist in a particular case.").

58. See Cressey, Other People's Money, supra note 16 , at 153 ("The theory ... has few practical implications either for prevention and detection of trust violation or for treatment of apprehended offenders.”).

59. Green, supra note 42 , at 102.

6o. See Cressey, Other PeOple's Money, supra note 16 , at 22-25.

61. Id. at 70 ; see also $i d$. at 31 (finding "as evidence of validity" that none of the cases contradicted his hypothesis). However,

[t]rust violators had to report whether in the past they conceived of themselves as having had any other non-shareable financial problem, whether adequate rationalizations and the other factors were present at the time, data which would appear difficult to recall because they required subjective interpretations of past events rather than facts.

Clinard, supra note 54 , at 363 .

Cressey also discusses a case in the literature that included consideration of the brother of an inmate who, like the inmate, was a bank manager, but who had not embezzled. CRESSEY, OTHER PEOPLE's MONEY, supra note 16 , at $45^{-47}$.

62. See Alexander Schuchter \& Michael Levi, Beyond the Fraud Triangle: Swiss and Austrian Elite Fraudsters, 39 ACCT. F. 176, 184 (2015) [hereinafter Schuchter \& Levi, Beyond the Fraud Triangle] ("Data acquisition in this area of research commonly takes place after the perpetrator has committed a crime, so one might regard retrospective reflections-even if believed by offenders themselves-as being contaminated by post-event processes, rather than as a 'black box' flight recorder."). 
may be incorrect; the inmates' "rationalizations [may instead have] emerged afterward to repress feelings of guilt."63

Third, Cressey interviewed only inmates, so his theory was largely derived from trust violators who were actually caught, prosecuted, found guilty, and incarcerated. ${ }^{6}$ It is possible that the commonalities Cressey found would not be true of embezzlers who were not incarcerated. ${ }^{6} 5$ For example, judges and juries may find trust violators who had a problem of an embarrassing nature such that the embezzler kept it secret less sympathetic or more "guilty" than individuals who embezzle for a non-illicit or altruistic motive, such as to help an ill family member. Individuals in the latter category may thus be less likely to be convicted or to receive a prison sentence. Thus, Cressey's study may suffer from selection bias when generalized beyond inmates.

Fourth, Cressey's findings may be culture-specific, reflecting the context for U.S. males in the early $195^{\text {os }} .^{66}$ One aspect that may reflect Cressey's era and his focus on men is that some of his interviewees mentioned that they kept their financial troubles from their wives. ${ }^{67}$ In fact, Cressey's "specific hypothesis ... was unknowingly suggested by a prisoner who stated that he believed that no embezzlement would ever occur if the trusted person always told his wife and family about his financial problems, no matter what the consequences." 68 This obviously assumes an embezzler who is male and married to a woman. ${ }^{69}$ In direct contrast with Cressey's findings, a 1974 article by Gwynn Nettler considering six Canadian embezzlement cases notes that in

63. Green, supra note 42 , at 103 .

64. See Cressey, Other PeOple's Money, supra note 16 , at 22-25.

65. See Clinard, supra note 54, at $36_{3}$ ("The results might be different if other samples of undetected violators, those discovered and not prosecuted because of restitution, etc., or those placed on probation were studied using his hypothesis.").

66. Cf. Grace Mui \& Jennifer Mailley, A Tale of Two Triangles: Comparing the Fraud Triangle with Criminology's Crime Triangle, 28 ACCT. RsCH. J. 45, 47 (2015) ("[T] he Fraud Triangle is unique to the societal context of the USA (Czielewski, 2012), which is a consequence of its origins in the USA (Cressey, 1953; Sutherland, 1940, 1944).”).

67. See Cressey, Other PeOPle's Money, supra note 16, at 71 (quoting Case 116 as stating, "Even my wife didn't know.").

Jonson and Geis state, "it is noteworthy that not one of the married men in the sample was able to share his dilemma with his wife." Jonson \& Geis, supra note 23, at 226. It is not clear if Cressey covered this specific issue with every married inmate in the sample, however. Also, it appears that at least one or two of the men's wives knew of the financial difficulties at some point. See supra note 42 and accompanying text. Additionally, it is possible that the men Cressey excluded from the sample because they did not accept the position of trust planning to hold the money in trust in good faith had shared more information with their intimates.

68. Cressey, OTHER PeOPLE'S MONEY, supra note 16 , at 28.

69. Some of the inmates' wives may have been kept in the dark about their husbands' finances more broadly. At least one of Cressey's interviewees mentioned that his wife did not know how much he earned. See id. at 43 (quoting Case 33, "[My wife] never knew how much I made."); $c f . i d$. at $5^{\circ}$ (quoting Case 99, "I gave [my wife] the impression right along that I'm going great guns. Why should I tell her and worry her about it?"); $i d$. at 62 (quoting Case $30_{5}$, "I suppose I should explain here, that I never bothered [my wife] with any of my troubles; after all, she was concerned with raising the children-she had a tough enough time of it." (alteration in original)). 
one case "the 'problem,' how to keep the beloved land, was not unshared. It was fully and repetitively discussed with the embezzler's wife." $7^{\circ}$

Fifth, Cressey's work has been criticized as focusing on "individualistic explanations of criminal behavior, overlooking the micro-sociological (one's immediate social and organizational environment) as well as macro-sociological explanations (broader historical, economic, and political factors)." ${ }^{11}$ Morales et al. state that "Cressey's work is thus based on a very particular conception of white-collar crime that marginalizes social environments and circumstances." 72

Given the limits of Cressey's sample and study design, Cressey's three factors should not be viewed as a definitive statement regarding the causes of embezzlement, even when examining the problem from an offender-focused perspective. And in fact, Cressey regarded the project as one in search of a case that would falsify his hypothesis.73 Subsequent studies have found cases that are inconsistent with Cressey's factors. For example, Nettler's 1974 article on six Canadian cases involving large embezzlements found that "in only one of these six instances was it possible to construct a parallel between the embezzling career Cressey portrays and the facts of our Canadian cases." 74 Nettler noted the absence of a non-shareable problem, stating, "[d] esire and opportunity generate theft more frequently in these instances than does a financial difficulty kept privy." 75 Nettler also found that " $[\mathrm{t}]$ hese five exceptions to Cressey's singular road to fraud are more clearly described as individuals who wanted things they could not afford and who were presented with (or who invented) ways of taking other people's money." ${ }^{6}$

In 1981, Dorothy Zietz published a study on female trust violators in the California Institution for Women.77 For purposes of comparing her findings with Cressey's, Zietz excluded from her initial sample inmates who had an ex ante intent to steal or defraud. $7^{8}$ She found that the "opportunity" aspect

7o. Nettler, supra note 27 , at $74-75$.

71. Morales et al., supra note 19 , at 176 (citation omitted).

72. Id.; cf. Schuchter \& Levi, Beyond the Fraud Triangle, supra note 62, at 185 ("Granted, as is usually the case with models, the FT does still offer an incomplete but useful abstraction of complex interactions, it nevertheless neglects the impact of social systems on individual decisions to commit fraud."). However, the accounting standards that rely on the fraud triangle include the context of a pressure-filled environment as part of the "rationalization" prong. The standards state that "even otherwise honest individuals can commit fraud in an environment that imposes sufficient pressure on them." CODIFICATION OF ACCT. STANDARDS \& PROCS., Clarified Statements on Auditing Standards, AU-C § 240.A1 (AM. INST. OF CERTIFIED PUB. ACCTS. 2020); ISA 240, supra note 10, II A1.

73. CRESSEY, Other PeOPle's MONEY, supra note 16 , at 32 .

74. Nettler, supra note 27 , at 74 .

75. Id.

76. Id. at 75 .

77. DOROThY ZietZ, WOMEN Who EMBEZZLE OR DEFRAUd 23-24 (1981). The initial sample was 100 women. Id. at 24 .

78. Id. at 25 . She considers those women separately, but it is not clear how many women that included. See id. at 87-123 (Part III, titled "Women Who Intended to Steal or Defraud"). 
applied just as it had in Cressey's study.79 However, she found differences with respect to the other two factors, with differences from Cressey's first factor (a non-shareable problem) most substantial. For example, in some cases, the financial need was caused by a husband or child's need for medical care-a "shareable" type of problem. ${ }^{80}$ Zietz found Cressey's third factor, rationalization, applicable, but she also found that rationalizations may differ for women, due to gender-based norms. ${ }^{81}$ Zietz concluded that, although her findings could not necessarily be extrapolated to all female trust violators, she had found negative cases that did not fit Cressey's three-part generalization. ${ }^{82}$

Thus, Cressey and Zietz found somewhat different commonalities among the convicted embezzlers they each studied. Yet, the factors that they, as well as Svend Riemer, whose work is discussed below, ${ }^{8}$ found central to trust violations can all be characterized as consisting of (1) a financial motive; (2) an opportunity to commit the violation; and (3) a role for psychological aspects in the offender's decision-making.

\section{B. "Fun WHILE IT LASTED": THE ROLE OF EXPERIENTIAL LEARNING}

An aspect that the fraud triangle's prongs do not specifically address is learning from the embezzlement experience-particularly learning that trust violations are not promptly detected. Cressey's study did not focus on this issue, probably because his interest was in what prompted a trusted individual to first betray that trust. ${ }^{8} 4$ Some learning may lead to subsequent violations. That is, someone who starts by embezzling a small amount may increase it over time, both as financial pressures or desires increase but also as the early violations go undetected.

Learning has a role in the "opportunity" element because undetected early violations may make the opportunity seem to continue or enlarge. With respect to the rationalization prong, learning that not all violations of trust are detected may help empower the individual to rationalize that the funds are not missed or that the behavior is not that bad since it is not being

79. Id. at 62. Zietz notes that "most of these women had been employed as bookkeepers, accountants, or clerks responsible in some way for other people's money." Id.

8o. Id. at 76 . In other cases, the embezzler was encouraged by trying "to retain or regain the affections of [her husband]," so the situational context was not kept from him. Id.

81. Id. at 77 ("[C] ultural ideologies affecting the development of their role models (such as wife, mother, and daughter) will need to be recognized as possible sources for the vocabularies of adjustment used by women.”).

82. Id. Zietz recognizes possible selection bias:

$[\mathrm{F}]$ urther research is needed to determine ... whether the results are skewed by the fact that many women are not sentenced to a state prison after trust violation (for example, women with small children, or women able to plea bargain when employers are reimbursed by relatives or a bonding company).

Id.

83. See infra text accompanying notes 1 18-28.

84. See supra text accompanying note 28. 
punished..$_{5}$ For example, in Cressey's Case $5^{6}$, discussed in connection with the awareness of the opportunity, the individual states:

I needed money very badly, and at first I didn't think of taking it from company funds. . . I sat up all one night drinking . . . In the morning I . . went down to work and took some money $\left(\$ 15^{0}\right)$ out of the safe. I reasoned that I was going to pay it back in three or four days, and I did pay it back. In a matter of a few days I took some more-it got easier as time went on. . . The most I ever took at one time was about $\$ 1$,ooo in one twenty-four hour period. ${ }^{86}$

In this example, the individual faced financial pressure (the first element of the triangle), eventually perceived the opportunity to take money from the safe at work (the second element), and rationalized it as a "loan" (the third element). The process of "borrowing" and "repaying" provided learning that eased the process and allowed him to increase over time the amount taken.

The situation that Bruce McNall-a coin dealer, Hollywood producer, and hockey team owner who eventually pled guilty to bank fraud ${ }^{87}$-describes in his co-authored autobiography, Fun While It Lasted, ${ }^{88}$ provides another illustration. McNall's financial troubles apparently began when the largest client of his business selling ancient coins, Bunker Hunt, was trying to sell a substantial amount of silver. ${ }^{8}$ Hunt's difficulties had arisen because, after silver was selling for as high as $\$ 5^{\circ}$ per ounce in January 1980 , "[b]y early spring, Bunker ... [was] committed to buy vast quantities of silver at $\$ 35$ an ounce in a market where it was worth about \$1 2."9o McNall explains that when he

presented [Bunker Hunt] with a list of ancient coins I thought he should buy, Bunker suggested a bit of creative financing that would help him shed more silver than the law allowed. Instead of paying cash for the coins, he would give me, in private, \$20 million worth of silver that he had in storage ... . I could sell it right away or hold it. $9^{1}$

85. The fraudster may also become desensitized to the feeling of having committed a bad act. Dorminey et al., Evolution of Fraud Theory, supra note 32, at 566 ("After the criminal act has taken place, especially if the fraud has taken place for a long period of time, the rationalization will likely be abandoned or cognitively dismissed. As the act is repeated, the perpetrator becomes de-sensitized.").

86. Cressey, Other PeOPle's Money, supra note 16 , at 90.

87. See Sports Executive Enters Guilty Plea, N.Y. TIMES (Dec. 15, 1994), https://www.nytimes.com/ 1994/12/15/business/sports-executive-enters-guilty-plea.html [https://perma.cc/BQ9Z-5TU7].

88. See generally Bruce McNall With Michael D’Antonio, Fun While It Lasted: My Rise AND FALL IN THE LAND OF FAME AND FORTUNE (2003) (telling McNall's story).

89. See id. at 71 .

9o. Id. at 68 .

91. Id. at 71. McNall does not express concern about financing that was apparently designed to circumvent applicable law. In part, that may be because of the value of the client to him. Also, other descriptions in the book suggest that McNall was already comfortable at that point with 
This approach was attractive to McNall because "Bunker was working ... to try to make the price go back up. He was sure that the market was just in a short-term dip." ${ }^{2}$ Although Bunker did not know it, McNall did not actually have the coins he had suggested that Bunker buy.93 McNall decided to "gamble with the price of silver" and hope to make a few million dollars once the price rose, then acquire the coins.94 McNall explains that "I took the risk with Bunker's investment because my relationship with him had grown so close, so familiar. I also felt comfortable doing it because I was making lots of money for him, especially with horses." 95

Unfortunately for McNall, the value of silver declined to six dollars an ounce and McNall did not have the funds to buy the coins. $9^{6}$ McNall rationalized lying to Bunker about his possession of the coins on the basis of numerous favors he had done for Bunker in the past, including money McNall had lost 97 in helping Bunker report a tax loss. $9^{8}$ When auditors demanded to see the coins, McNall, with the help of his staff, bought some of the coins on the list, borrowed some, and relabeled another important client's coins. 99

Unexpectedly, the auditors took the collection McNall had labeled as Bunker's, making McNall unable to return the coins to their owners as planned. ${ }^{100}$ McNall learned from this experience that his staff would help him unquestioningly:

I was pleasantly surprised when not one person hesitated to help. But I was astounded when, in the end, not one pointed out that I had been reckless, even fraudulent, in my dealings. Later I would realize that they were all too dependent on me to see any other course. ${ }^{101}$

some level of legal transgression (such as smuggling coins out of Tunisia). See infra text accompanying notes $103-07$.

92. MCNALl \& D'ANTONiO, supra note 88, at 71. The Hunt brothers are known to have "attempted to manipulate the price of silver in 1979." Gina-Gail S. Fletcher, Benchmark Regulation, 102 IOWA L. REV. 1929, 1939 (2017). Professor Fletcher explains that "regulators became aware of their schemes in a matter of months because of the observable impact it had on the price of silver." Id.

93. MCNALl \& D'ANTONIO, supra note 88, at 71 .

94. Id. at 72 .

95. Id.

96. Id. at 73. Schuchter and Levi state regarding the first element of the fraud triangle, "[w] hat was once a mere incentive can turn into pressure to continue." Schuchter \& Levi, Revisited, supra note 14, at 110.

97. MCNALl \& D'ANTONIO, supra note 88, at 73 ("The millions of dollars I had shoveled to Bunker for horses; the Tunney-brokered bailout; the $\$ 65$ o,ooo I lost on that New Year's Eve silver deal; all of that was in my mind as I continued to lie to Bunker about the coins I had supposedly bought for him after he gave me all that silver.").

98. Id. at 64 (describing the New Year's Eve transaction).

99. $\quad I d$. at $73-76$.

1oo. Id. at $76-77$.

101. Id. at 74 . 
McNall recounted that "[r]ather than feeling chastened and humbled, [he] felt as if [he] had made a great escape" and "had taken a risk, and survived." In other words, McNall learned from this experience, but he felt that he learned the wrong lesson-he could get away with this kind of illegal activity.

Although this series of events seems to have been where the trouble that eventually landed McNall in prison began, it does not appear to be his first transgression. He describes smuggling antique coins out of Tunisia as a young man, where "the removal of antiquities was punishable by a twenty-year prison term." ${ }^{\circ}$ McNall explains that this was before most airports had metal detectors, so he and his traveling companion, the 16-year-old son of an ancient coin expert, ${ }^{104}$ "selected the most valuable ones and put them in our pockets, in our shoes, even in the cuffs of our pants. The rest ... were ... distributed in our luggage." ${ }_{105}$ When asked at the airport if they "were transporting any national treasure," they simply said no. ${ }^{106}$ This type of experience may be an early example of learning that opportunities existed for enrichment despite legal prohibitions. ${ }^{107}$ Thus, McNall's story provides a window into how initial trust violations can provide a learning experience that may foster subsequent violations.

\section{MisconcePtions About The Fraud Triangle}

Some of the origins of the fraud triangle, including the source of its name, are subject to differing claims. This Part examines the competing claims about the origins and development of the fraud triangle in an effort to clear up confusion in the literature.

\section{A. THE SOURCE OF THE FACTORS}

The source of the triangle's three factors is sometimes disputed. ${ }^{108}$ For example, Professors Schuchter and Levi point to a source other than Cressey

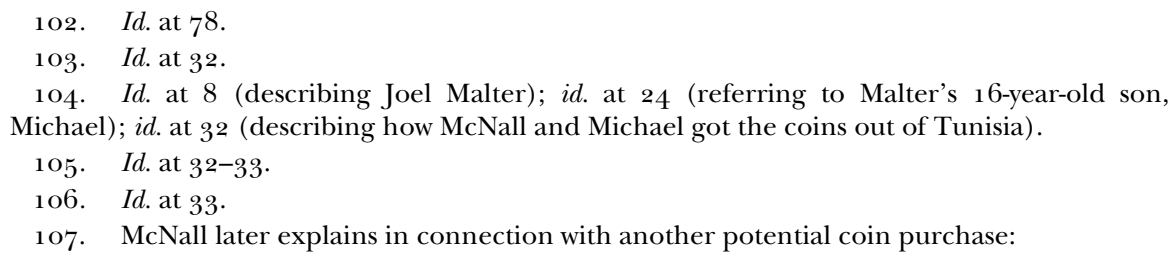

Like every other retailer in the world, I wasn't much concerned with the coins' origins. If you investigate thoroughly you will discover that at some point, virtually every ancient coin on the market was smuggled, stolen, or otherwise the subject of shady dealing.... It's a state of affairs that is widely accepted, even by lawenforcement authorities, and only leads to problems when questions about a sale become public.

Id. at 64 .

108. One scholar has argued that Cressey's three factors are "loosely based on what policemen and detectives have referred to as 'means, motives, and opportunity.'" Ramamoorti, supra note 51 , at 525 . Cressey's first factor, a non-shareable problem, involves motive, and Cressey does list opportunity. Opportunity may also include means, although means may be more closely analogous to a fourth factor added by the "fraud diamond." See Wolfe \& Hermanson, supra 
for the idea behind the fraud triangle. They state that "the original idea came largely from a European, Svend Riemer (1941)." ${ }^{\circ}$ 9 Riemer, like Cressey and Sutherland, was a sociologist. Schuchter and Levi note that Cressey's book cites Riemer in his discussion of opportunity, and "Riemer points out that a potential fraudster needs a situation, which offers an opportunity; a driving force in an emergency situation, which may consist of a plurality of environmental constellations; and psycho-pathological conditions have to be considered as well." 110 Schuchter and Levi "hypothesize that Cressey was strongly inspired by Riemer's work when developing an initial Fraud Triangle approach." ${ }_{111}$

Cressey was certainly aware of the relevance of Riemer's work. The "Review of the Literature" section of Cressey's 1950 Ph.D. dissertation states that "only three sociologists have published detailed accounts of research on embezzlement." ${ }^{112}$ Riemer is one of them, and Cressey summarizes Riemer's article. ${ }^{113}$ In addition, although it may not be well known, Cressey and Riemer were colleagues on the "sociology faculty"114 at the University of California, Los Angeles for about a year prior to the time Cressey published the 1953 book that grew out of his dissertation research. ${ }^{115}$ However, Riemer's study —although also conscious of Sutherland's "differential association" theory of crime $^{116}$ - had a very different focus than Cressey's. In addition, Cressey's

note 13 , at $38-40$ (proposing the addition of a "capability" factor). Moreover, Cressey includes an additional factor, "rationalization," which focuses on psychological aspects of the violation. See Cressey, Trusted Persons, supra note 27, at 578 .

109. Schuchter \& Levi, Beyond the Fraud Triangle, supra note 62, at 177 (citation omitted).

110. Schuchter \& Levi, Revisited, supra note 14, at 108.

111. Id.; see also supra text accompanying note 109 .

112. Donald Ray Cressey, Criminal Violation of Financial Trust 20 (May 1950) (Ph.D. dissertation, Indiana University) (on file with author) [hereinafter Cressey, Dissertation].

113. Id. at 23-25.

114. At the University of California, Los Angeles ("UCLA"), Sociology did not become its own department until 1964-65. History: UCLA Sociology Chairs, UCLA COLL. SOC. SCIS.: SociO., https://soc.ucla.edu/content/history [https://perma.cc/8ZBY-GPDC].

115. Cressey joined the UCLA faculty in 1950. Akers \& Matsueda, supra note 18, at 424. He remained there until he moved to U.C. Santa Barbara in 1961. Id. Riemer joined the UCLA Sociology faculty in $195^{2}$, moving there from the University of Wisconsin. Ivan Light, Svend Henry Riemer, Sociology: Los Angeles, in UnIVERSITy OF CALIFORnia: In MEMORIAM, SEPTEMBer 1978, at 145, 146 (1978), http://texts.cdlib.org/view?docId=hb4q2nb2nd\&brand=calisphere\&doc.view =entire_text [https://perma.cc $\left./ \mathrm{H}_{5} \mathrm{TD}-\mathrm{MD}_{5} \mathrm{~L}\right]$. Riemer remained at UCLA until he retired in 1972. Id. at 145. Thus, Cressey and Riemer were colleagues from $195^{2}$ to 1961 .

Cressey conducted substantial work on his book after joining the UCLA faculty, including adding interviews with inmates of two additional prisons. In his dissertation research, "[t]he main source of direct information on trust violation was interview material obtained from prisoners at the Illinois State Penitentiaries at Joliet, Illinois." Cressey, Dissertation, supra note 112 , at 40 . He conducted the Chino, California interviews from October $195^{\circ}$ to May $195^{1}$, presumably after he moved to California. CRESSEY, OTHER PEOPLE'S MONEY, supra note 16, at 22 -23 . He conducted the Terre Haute, Indiana interviews from June to August 1951. Id. at 23. This was to add a federal prison. See supra note 29 and accompanying text.

116. See Svend H. Riemer, Embezzlement: Pathological Basis, 32 J. Crim. L. \& CriminOlOGY 411 , $412 \mathrm{n} .3$ (1942) (citing Sutherland, White-Collar Criminality, supra note 19, and stating, "[o] ur field of observation, however, does not permit any definite conclusions as to the validity of 
framework grew out of interviews during which he tested and rejected the theories of several scholars, including Riemer.

On the first point-the focus each scholar had-Cressey was explicitly interested in developing a theory regarding what factors caused a previously honest individual to become a trust violator. ${ }^{17}$ By contrast, Riemer's 1942 article, "Embezzlement: Pathological Basis," focused on cases involving medical pathologies. ${ }^{118}$ The study was based on analysis of the case files of 100 convicted embezzlers from a "prison clinic in Stockholm, Sweden."119 The inmates in the prison clinic were those for whom someone had raised the defense of not guilty by reason of insanity. ${ }^{120}$ Based on this population, Riemer developed six "Socio-genetic Types of Embezzlement." ${ }^{121}$

Riemer begins his article by listing three factors relevant to the "conflict situation in which the criminal act originates": "1) the social pull; the opportunity," "2) the social push; the emergency situation," and "3) specific to our material; the psycho-pathological element involved." 122 As the title of his article and this wording suggests, Riemer's principal focus was on the third factor. ${ }^{123}$ Riemer therefore considered the psychiatric classification (or "pathological tendencies") of each individual. ${ }^{24}$ For example, he described some of the

Sutherland's thesis"). Two of the four citations in Riemer's article are to Sutherland's work. In addition to the one cited just above, Riemer cites to Sutherland's textbook, along with another textbook. See id. at 413 n.4 ("The need of investigations into 'behavior systems' or 'behavior sequences' of crime has been stressed repeatedly in the methodological discussions of recent textbook editions. Cp. E. H. Sutherland and Walter C. Reckless.”).

117. See supra text accompanying notes 27-32; see also Cressey, Dissertation, supra note 112 , at 1 ("The objective of this study is the isolation and definition of the processes involved in violating, in a criminal manner, positions of financial trust which have been accepted in good faith.")

118. See Riemer, supra note 116, at 411-12.

119. Id. at $411 \mathrm{n} .1$.

120. Id. ("Only such cases are transferred to the prison clinic in behalf of which insanity is pleaded by either defense, judge or district attorney.”). Riemer's cases included both men and women. See id. at 423 .

121. Id. at $4^{17}$; see also $i d$. at $417^{1-23,420}$ tbl.IV (listing the six types).

122. Id. at $4^{11}$ (emphasis added). The source of the factors is not stated. See id. at 411-14. The terms "social pull" and "social push" are not original with Riemer. See, e.g., ARLAND D. WEEKS, SOCIAL ANTAGONISMS 6 (1918) (using the term "social pull”).

123. Riemer termed that "specific to our material." Riemer, supra note 116, at 411; see also $i d$. at $412 \mathrm{n} .3$ (noting that, due to the setting, "[o] ur attention is limited to mainly pathological cases").

Riemer does spend a few pages discussing the other factors. With respect to "opportunity," Riemer pointed to trust that can be exploited by someone engaged in a business transaction. $I d$. at 412 ("[T] he individual member of the group must to some extent be trusted to adhere to certain folkways concerning money transactions. These loopholes represent the opportunities that are open to the embezzler."). Regarding the "emergency situation," Riemer found that "[e]mbezzlement in the great majority of cases represents the only way out of an extreme economic emergency situation." Id. at 414. A declining career, including risk of losing the family home, was a prime example. $I d$.

124. Id. at $4^{19}$ tbl.III; see also id. at $4^{16}$ (considering "the traditional psychiatric classification of reaction patterns as an additional approach to the discussion of pertinent environmental 
embezzlers as paranoid, depressive, manic, or suicidal. ${ }^{125}$ Some he labelled as suffering from alcoholism in addition to another classification. ${ }^{126}$

On the second point-how Cressey developed his theory-Cressey describes in his book developing a series of hypotheses based on the work of previous scholars. Cressey's first hypothesis was based on his mentor Edwin Sutherland's writing on white collar crime ${ }^{127}$ and was that

the incumbent has learned in connection [with] the business or profession in which he is employed that some forms of trust violation are merely technical violations and are not really "illegal" or "wrong," and, on the negative side, that they are not violated if this kind of definition of behavior has not been learned. ${ }^{128}$

Cressey quickly rejected this first hypothesis because some of the interviewees said they did not know anyone else behaving similarly, others defined the behavior as theft, and some trust violators "expressed the idea that they knew the behavior to be illegal and wrong at all times and that they had merely 'kidded themselves' into thinking that it was not illegal." 129

Cressey then developed a second hypothesis "in part based on Riemer's observation that the 'opportunities' inherent in trust positions form 'temptations' if the incumbents develop anti-social attitudes." $13^{\circ}$ The framing of this hypothesis required Riemer's element of an emergency situation to be present. ${ }^{131}$ Cressey abandoned this approach "when persons were found who

constellations"). Riemer stated "that [his] interest is related entirely to the ensuing distortion of the definition of the situation." $I d$.

125. Id. Riemer did not find pathological tendencies in all of the subjects. See id. at $4^{1} 9$ tbl.III (noting no pathological tendencies in such cases as Case 74, involving a post official, and Case 77 , involving a police officer).

126. Id.

127. This was the case despite the fact that in his book, Cressey stated that the trust-violation crimes he studied did not constitute "white collar crime" as defined by Sutherland because

Sutherland has defined that type of crime as violation of law by persons of respectability and high social status in the course of their occupations. . . While the crimes of trust violators are committed in the course of their occupations, many of the violators encountered cannot be considered as persons of high social status or as respected persons of the community.

CRessey, OTHER PeOPle's Money, supra note 16 , at 184 n.9 (citing SuTHERLAND, supra note 26 , at 9$)$.

128. Id. at 27 (citing SUTHERLAND, supra note 26).

129. Id.

13o. Id. Riemer stated in this regard:

[T] he individual member of the group must to some extent be trusted to adhere to certain folkways concerning money transactions. These loopholes represent the opportunities that are open to the embezzler. They form a temptation if the embezzlers develop an anti-social attitude that makes possible an abandonment of the 'folkways' of business behavior.

Riemer, supra note 116 , at $412-13$.

131. Cressey explained:

The formulation was that positions of trust are violated when the incumbent 
claimed that while an emergency had been present at the time they violated the trust, other, perhaps even more extreme, emergencies had been present in earlier periods when they did not violate it." ${ }^{132}$

Cressey then shifted to a hypothesis involving the "psychological isolation" of a non-shareable problem, based on work by LaPiere and Farnsworth;'133 rejected that based on interviewees' statements; and ultimately formed the final three-factor hypothesis, ${ }^{134}$ for which he did not find a negative case.

Thus, Cressey was influenced by prior work on white-collar crime and embezzlement, including Riemer's work, but Cressey's focus was different from Riemer's. Riemer's article focused primarily on the pathologies of embezzlers, while Cressey was interested in what caused a previously trustworthy person to commit the first trust violation. The three factors on each list share the "opportunity" factor, and Cressey credits "Riemer and others who have written on embezzlement [as] hav[ing] used the term 'opportunity' to refer to the position of trust which a person must necessarily hold before he can embezzle." ${ }_{135}$

Riemer and Cressey's lists differ most on the third factor, with Riemer pointing to a "psycho-pathological element" and Cressey to a mere "rationalization." ${ }_{136} 6$ The evolution of the factors as they were extended from embezzlement to contexts such as accounting fraud shares does not involve medical pathologies. The next Section discusses this evolution.

\section{B. THE FACTORS' PATH FROM EMBEZZLEMENT TO FRAUD}

As noted above, current U.S. and international auditing standards reflect the teachings of the fraud triangle. ${ }^{137}$ Those standards list the factors as incentive or pressure, perceived opportunity, and rationalization. ${ }^{13}{ }^{8}$ The

structures a real or supposed need for extra funds or extended use of property as an "emergency" which cannot be met by legal means, and that if such an emergency does not take place trust violation will not occur.

Cressey, Criminal Violation, supra note $4^{1}$, at $74^{1}$.

132. Id.

133. Cressey, Other PeOPle's MONEY, supra note 16, at 28.

134. See supra text accompanying note 36 (describing Cressey's conclusions and findings).

135. Cressey, Other PeOple's Money, supra note 16, at 173 n.1. Riemer was not the first to refer to the "opportunity" aspect of the crime of embezzlement. For example, a 1926 article states that "[t] he fundamental causes for bank defalcations are two: first, a desire for something; and secondly, the opportunity to gratify that desire." William Ashdown, The Psychology of Embezzlement, 112 BANKERS' MAG. 519, $5^{21}$ (1926).

136. Compare supra text accompanying notes 123-24 (discussing Riemer's third factor), with supra text accompanying notes 48-49 (discussing Cressey's third factor).

137. See supra text accompanying note 10.

138. Codification of ACct. Standards \& Procs., Clarified Statements on Auditing Standards, AU-C $§ 240 . A 1$ (AM. InST. OF CERTIFIED PUB. ACCTS. 2020); ISA 240, supra note 10, Il A1. 
standards also use these three elements to help categorize "risk factors" for fraud. 139

The auditing standards describe the first prong as generally financial in nature. ${ }^{14^{\circ}}$ The statement regarding "perceived opportunity" for fraud is brief and points to an individual's ability to override internal controls. ${ }^{14^{1}}$ Finally, the standards describe the "rationalization" prong as relating either to personal characteristics of the individual or resulting from a pressure-filled environment:

Individuals may be able to rationalize committing a fraudulent act. Some individuals possess an attitude, character, or set of ethical values that allow them knowingly and intentionally to commit a dishonest act. However, even otherwise honest individuals can commit fraud in an environment that imposes sufficient pressure on them..$^{1{ }^{2}}$

139. See Codification of ACCT. Standards \& Procs., Clarified Statements on Auditing Standards, AU-C $\$ 240.11$ (AM. INST. OF CERTIFIED PUB. ACCTS. 2020); ISA 240, supra note 10, at app. 1 .

140. See Codification of ACct. Standards \& Procs., Clarified Statements on Auditing Standards, AU-C § 240.Aı (AM. INST. OF CERTIFIED PUB. ACCTS. 2020); ISA 240, supra note 10, I A1. The language generally is identical. The International Auditing Practices Committee ("IAPC") and U.S. Auditing Standards Board ("ASB") apparently worked closely together. According to the International Federation of Accountants the history is as follows:

In March 2001, the IAPC issued ISA 240. In March 2001, the US ASB invited representatives of the IAPC to attend meetings of the US ASB's Fraud Task Force. The IAPC accepted the invitation with the view to obtaining an understanding of the development of a revised US SAS 82 so that ISA 240 could be revised to converge with the final revised US SAS 82 , subject to any differences necessary to take account of the international environment. In February 2002, the US ASB issued an exposure draft Consideration of Fraud in a Financial Statement Audit. The IAASB issued a response letter to this exposure draft. In October 2002, the US ASB issued SAS 99.

Auditor's Responsibility, supra note 12.

141. Codification OF ACCT. StAndards \& Procs., Clarified Statements on Auditing Standards, AU-C § 240.Aı (AM. INST. OF CERTIFIED PUB. ACCTS. 2020) ("A perceived opportunity to commit fraud may exist when an individual believes internal control can be overridden ...."); ISA 240, supra note 10 , Il A1 (same).

142. Codification of ACct. Standards \& Procs., Clarified Statements on Auditing Standards, AU-C $§$ 240.A1 (AM. INST. OF CERTIFIED PUb. ACCTS. 2020) (emphasis added); ISA 240, supra note 10, If A1 (emphasis added). Donegan and Ganon criticized the AICPA standards for what they see as an approach that exonerates the culture of the employer, stating that:

The triangle had the . . . advantage of explaining fraud as the action of a loner driven by need, taking advantage of a lack of internal control. Thus . . . the search for the culprit could focus on individual offenders, not on the culture that may have encouraged and rewarded their actions.

James J. Donegan \& Michele W. Ganon, Strain, Differential Association, and Coercion: Insights from the Criminology Literature on Causes of Accountant's Misconduct, 8 ACCT. \& PUB. INT. 1, 3 (2008).

However, as the quotation in the text shows, the auditing standards' discussion of the "rationalization" prong refers to fraud resulting from sufficient pressure in the individual's environment. In addition, in the "incentive or pressure" prong, the AICPA focuses first on employment-related pressures, and only then on lifestyle pressures:

Incentive or pressure to commit fraudulent financial reporting may exist when management is under pressure, from sources outside or inside the entity, to achieve 
In the "risk factors" section, this factor is termed "attitudes or rationalizations." 143

Regarding how these factors came to be included in auditing standards, several scholars explain that after high-profile accountants were convicted of fraud, the AICPA adopted the fraud triangle approach from the Association of Certified Fraud Examiners ("ACFE"). ${ }^{144}$ For example, accounting professors Donegan and Ganon state that, " $[\mathrm{w}]$ hen the AICPA belatedly recognized the need to consider why so many accountants were committing fraud they turned to the ACFE, which, in effect, meant embracing Cressey's perspective." ${ }^{145}$

The ACFE was founded in 1988 by Joseph T. Wells. ${ }^{14^{6}}$ Wells was heavily influenced by Cressey. ${ }^{147}$ In the early 1980s, Wells had connected with Cressey, and Wells "ascribes much of the credit for the founding of the ACFE to his relationship with Cressey." ${ }^{4} 8$ "The ACFE's mission is "to reduce the incidence of fraud and white-collar crime and to assist the Membership in

an expected (and perhaps, unrealistic) earnings target or financial outcome - particularly because the consequences to management for failing to meet financial goals can be significant. Similarly, individuals may have an incentive to misappropriate assets (for example, because the individuals are living beyond their means).

Codification of ACct. Standards \& Procs., Clarified Statements on Auditing Standards, AU-C § 240.A1 (AM. INST. OF CERTIFIED PUB. ACCTS. 2020) (emphasis added); ISA 240, supra note 10, I A1 (emphasis added).

143. Codification of ACct. Standards \& Procs., Clarified Statements on Auditing Standards, AU-C $\$ 240.11$ (AM. INST. OF CERTIFIED PUB. ACCTS. 2020); ISA 240, supra note 10, at app. 1 .

144. See Donegan \& Ganon, supra note 142, at 3; Mark E. Lokanan, Challenges to the Fraud Triangle: Questions on Its Usefulness, 39 ACCT. F. 201, 202 (2015) ("Concerned about the erosion of ethical standards within the accounting profession, the [AICPA] in 2002 and the [IFAC] in 20o6, followed the ACFE's footsteps and turned to Cressey's (1953) work on the fraud triangle for potential explanations of the frauds." (citation omitted)); Morales et al., supra note 19, at 182 ("The ACFE's claim to expertise, [is] grounded in the imagery of the triangle, spread beyond its confines," to both ISA 240 and to the AICPA in SAS No. 99).

145. Donegan \& Ganon, supra note 142, at 3 .

146. Morales et al., supra note 19, at 179; see also ACFE Leadership: Dr. Joseph T. Wells, CFE, CPA, ASS'N OF CERTIFIED FRAUD EXAM'RS, https://www.acfe.com/bio-jwells.aspx [https://perma.cc/ 4ZEM-KLG9] (providing Wells' biography).

147. WELLS, supra note 25, at 21-22 (describing his friendship with Cressey and stating that "although Cressey didn't know it at the time, he created the concept of what eventually became the Certified Fraud Examiner").

148. Donegan \& Ganon, supra note 142, at 3 (erroneously referring to Wells as "Joseph Walsh"). 
fraud detection and deterrence." ${ }_{149}$ The ACFE touts the fraud triangle as assisting in the detection of fraud. ${ }^{15}$

Donegan and Ganon find "problematic ... the generalization from a sample of embezzlers to those who have committed financial statement fraud." ${ }^{15}$ Fraud and embezzlement are not identical. Black's Law Dictionary's first definition of fraud is "[a] knowing misrepresentation or knowing concealment of a material fact made to induce another to act to his or her detriment." ${ }^{15^{2}}$ Fraud is thus a fairly broad category. By contrast, embezzlement is fairly narrow. Black's Law Dictionary defines embezzlement as "[t]he fraudulent taking of personal property with which one has been entrusted, esp [ecially] as a fiduciary." ${ }^{53}$

Given this critique, it is worth examining how Cressey's work was extended to financial statement fraud. Recall that Cressey's factors were (1) a non-shareable problem; (2) a perceived opportunity; and (3) rationalization, while the fraud triangle factors adopted by the AICPA are (1) incentive or pressure; (2) a perceived opportunity; and (3) character or rationalization. ${ }^{154}$ Thus, the factors that Cressey developed in his study of embezzlers were not simply copied over to the financial statement fraud context. The first and third factors changed somewhat.

149. Morales et al., supra note 19, at 179 (quoting Who We Are, Ass'N OF CERTIFIED FRAUD EXAM'RS, https://www.acfe.com/who-we-are.aspx [https://perma.cc/STG5-QTGW]). The ACFE provides anti-fraud training, and it provides a certification called "Certified Fraud Examiner." Membership and Certification, ASs'N OF CERTIFIED FRAUD EXAM'RS, https://www.acfe.com/ membership-certification.aspx [https://perma.cc/EN8S-SHV 5 ]. Mark Lokanan has criticized the ACFE's use of the fraud triangle, in part because the ACFE has something to sell: "[I]t makes sense that the ACFE uses the fraud triangle because the fraud triangle validates its very existence. The theory here, in short, is that one's chosen solution(s) actually specify or constitute the very problem that needs to be addressed." Lokanan, supra note 144, at 207.

15 o. See Morales et al., supra note 19, at 177 ("We found a . . tendency to generalize in ... ACFE documents, suggesting that ACFE representatives are highly confident in the knowledge base that allegedly underlies the fraud triangle concept. . . [T] he knowledge base claimed by the ACFE is presented as universal." (footnote omitted)); see also Videos - The Fraud Examiner: Why Do People Commit Fraud?, Ass'N Of CERTIFIEd Fraud EXAM'RS (Aug. 201 7), https:// www.acfe.com/content.aspx?id $=429499934^{6} \quad\left[\right.$ https: $/ /$ perma.cc $\left./ \mathrm{FF}_{3} \mathrm{~W}-\mathrm{XNT}_{5}\right]$ (describing the video as follows: "Explore how pressure, opportunity and rationalization-called the Fraud Triangle-can come together to influence an individual to commit fraud.").

151. Donegan \& Ganon, supra note 142, at 3; see also Wm. Dennis Huber, Forensic Accounting, Fraud Theory, and the End of the Fraud Triangle, 12 J. THEORETICAL ACCT. RSCH. 28, 30 (2017) (arguing that "the fraud triangle ... as originally developed and modified, has been misused, abused, contorted, stretched out of shape, and pressed into uses for which it was never intended and cannot possibly accommodate").

152. Fraud, BLACK's LAW DictionARY ( 11 th ed. 2019); $c f$. CODIFICATION OF ACCT. STANDARDS \& Procs., Clarified Statements on Auditing Standards, AU-C $\$ 240.11$ (AM. INST. OF CERTIFIED PUB. ACCTS. 2020) (defining fraud as " $[\mathrm{a}] \mathrm{n}$ intentional act . . . involving the use of deception that results in a misstatement in financial statements that are the subject of an audit").

153. Embezzlement, BLACK's LAW Dictionary ( 11 th ed. 2019). Embezzlement does not involve fraud in the receipt of the property, as the property is received legitimately but in a trustee or fiduciary capacity. However, embezzlement involves fraud in the conversion of the property to one's own use. See id.

154. See supra text accompanying notes $36-48,137-43$. 
There also seems to be some confusion regarding the source of these changes. Morales et al. link both of these changes to Joseph Wells, the founder of the ACFE, stating that “[a]s in Wells' writings (1997), the non-shareable financial problem has disappeared and been replaced by an incentive or pressure to commit fraud, while the notion of rationalization is linked with that of attitude, thus shifting closer to the idea of individual morality." ${ }_{55}$ The cite is to Wells' 1997 book, Occupational Fraud and Abuse. ${ }^{15}$ However, that does not appear to be the source of the changes. With respect to the first factor, Wells does not introduce the phrase "incentive or pressure." Instead, Wells hews closely to Cressey in this regard. He states in part, " $[\mathrm{t}]$ he role of the nonsharable problem is important," 157 and he includes a discussion under the heading "Nonsharable Problems" ${ }^{8}{ }^{8}$ after quoting Cressey's list of three factors and summarizing them. ${ }^{159}$

With respect to the third factor, Wells does not mention attitude or character per se, but he does say in his "Conclusion" section:

Our sense tells us that one model-even Cressey's-will not fit all situations. Plus, the study is nearly half a century old. There has been considerable social change in the interim. And now, many antifraud professionals believe there is a new breed of occupational offender -one who simply lacks a conscience sufficient to overcome temptation. ${ }^{160}$

Thus, Wells merely alludes to developments subsequent to Cressey's work that affect the third prong.

The origins of the changes in these two prongs likely lie elsewhere, in research on fraud. In 1979, certified public accountant ("CPA") Steve Albrecht and four other researchers conducted a study for accounting firm KPMG "to study fraud and how it could be detected." 161 They studied both

155. Morales et al., supra note 19, at 182 (citing WELLS, supra note 25). Morales et al. argue that "SAS 99 recommends calling in fraud examiners-identified as key participants in the antifraud effort-to work with the organizations' administrators and auditors." Id. at 183 . However, it appears that the reference to certified fraud examiners appears not in SAS No. 99 itself, see Codification of ACCT. STANDARds \& Procs., Statement on Auditing Standards No. 99 (Am. Inst. Of CERTIFIEd Pub. ACCTS. 2002), but in an exhibit that Morales et al. mention, see id. at 76 (including a paragraph that begins, "[c]ertified fraud examiners may assist the audit committee and board of directors with aspects of the oversight process either directly or as part of a team of internal auditors or independent auditors"). Wells is thanked in the exhibit as part of the "Anti-Fraud Detection Subgroup." Id. at 83 .

156 . Morales et al., supra note 19 , at 194 .

157. WELLS, supra note 25 , at 11 .

158. Id. This section spans more than two pages and includes subheadings on types of non-shareable problems. See id. at 11-14. This section remains similar in a related book of his, Joseph T. WElls, Corporate Fraud HANDbOOK: PREVENTION AND DETECTION 6-9 (2004), and subsequent editions of that book. See, e.g., Joseph T. WELls, Corporate FraUd HandBoOK: PREVENTION AND DETECTION 7-10 ( 5 th ed. 2017).

159. WELLS, supra note 25 , at 10.

16o. Id. at 20.

161. Albrecht, supra note 7, at 3. 
convicted fraudsters and the existing literature on the subject and compiled a list of "variables that appeared to influence or be associated with the perpetration of fraud." ${ }^{162}$ Their study identified 82 variables, or "red flags," which they classified into three categories. ${ }^{163}$

Based on this research, Albrecht et al. "concluded, similarly to Cressey, that it was the combination of three forces that produces a fraudulent act" $16_{4}$ : (1) "situational pressures," (2) "opportunities to commit fraud," $16_{5}$ and (3) "personal integrity (character)." 166 Albrecht et al. found that, in fraud cases, Cressey's first element did not have to involve something nonshareable. ${ }^{167}$ Albrecht explains: "Rather, we concluded that situational pressures refer to the immediate pressures that individuals experience within their environments. ... We concluded that the most overwhelming pressures are usually high personal debts or financial losses." 168 This "situational pressure" factor is similar to the AICPA's first factor, "incentive or pressure." 169 However, the term "incentive" did not appear either in Cressey's or Albrecht et al.'s first factor. For that, we have to look elsewhere.

A very similar phrase shows up in a report issued by the National Commission on Fraudulent Financial Reporting (known as the Treadway Commission, after its Commissioner) in $1987 .{ }^{170}$ The Treadway Commission's report found that:

162. Id.

163. Id.; cf. Marshall B. Romney, W. Steve Albrecht \& David J. Cherrington, Auditors and the Detection of Fraud, 149 J. ACCT. 63, 65-68 (1980) (including a "fraud risk" questionnaire organized into five major categories).

164. Albrecht, supra note 7 , at 3 .

165. Albrecht et al. found that opportunities to commit fraud can involve "careless internal controls" on the part of the employer, but can also involve openings "individuals create for themselves . . . . For example, ... [by] modifying the computer programs." Id.

166. W. Steve Albrecht, Marshall B. Romney, David J. Cherrington, I. Reed Payne \& Allan V. Roe, How to Detect AND PREVENT Business Fraud 37 (1982).

167. Albrecht, supra note 7 , at 3 .

168. Id. (emphasis added); see also Romney et al., supra note 163 , at 64 ("More likely, a situational pressure at a personal level, such as a debt or loss, would have to be combined with a predisposition to partial dishonesty in order for the crime to take place."). The "situational pressure" idea is similar to Riemer's "emergency situation." See supra text accompanying note 123. Albrecht et al.'s study also

dichotomized situational pressures into two groups: 1) those that encourage individuals to commit fraud for the company rather than against the company, such as not meeting analysts' forecasts of revenues, gross margin or earnings, delisting from a stock exchange or having a cash shortage and 2) those that encourage individuals to commit fraud against organizations.

Albrecht, supra note 7 , at 3 .

169. See supra text accompanying note 10. The rationalization aspect of the third factor was contained in Cressey's work. See supra text accompanying note $4^{8}$.

17o. See NAT'L Comm'n On Fraudulent Fin. Reporting, Report of the National COMMISSION ON FRAUDULENT FINANCIAL REPORTING 23 (1987) [hereinafter TREADWAY REPORT], https://www.coso.org/Documents/NCFFR.pdf [https://perma.cc/Y7TB-GT29]; see also Codification of ACCT. Standards \& Procs., Pre-Clarity Statements on Auditing Standards, AU 
fraudulent financial reporting usually occurs as the result of certain environmental, institutional, or individual forces and opportunities. These forces and opportunities add pressures and incentives that encourage individuals and companies to engage in fraudulent financial reporting and are present to some degree in all companies. If the right, combustible mixture of forces and opportunities is present, fraudulent financial reporting may occur. ${ }^{171}$

This report was well-received and influential. For example, the Securities and Exchange Commission and some of its members praised the Treadway Commission's report. ${ }^{172}$ SAS No. 99 cites the report. ${ }^{173}$ Thus, the "incentive" aspect of the first factor may have been drawn from that report.

As noted above, the Albrecht et al. study also shifted the third factor from "rationalization" to "personal integrity (character)." 174 That study further "stated that it was easier for someone with lower or situational integrity to rationalize engaging in fraudulent behavior." ${ }_{175}$ This focus on personal character contradicts Edwin Sutherland's view that crime is determined by environment rather than by personal, moral failings. However, it is consistent with the AICPA's statement that “[s] ome individuals possess an attitude, character, or set of ethical values that allow them knowingly and intentionally to commit a dishonest act." ${ }_{17}^{6}$ Thus, Albrecht et al.'s work may have influenced the AICPA.

A few years later, Loebbecke et al. developed their own three-factor model. Their model:

asserts that for ... fraud to occur, (1) the conditions of the entity must be such that a material management fraud could be carried out; (2) the person or persons who would commit the fraud must have a reason or motivation for doing so; and (3) the person or persons who

$\S 316.04$ n.3 (AM. INST. Of CERTIFIED PUB. ACCTS. 2014) (referring to the commission as the Treadway Commission).

In trying to ascertain the causes of financial reporting fraud, the Treadway Commission interviewed numerous experts and "the Commission's staff completed more than 20 research projects and briefing papers, including analyses of SEC enforcement actions, pressures within public accounting firms, AICPA self-regulatory programs, and the legal and regulatory environment." TREADWAY REPORT, supra, at 3 .

171. TREADWAY REPORT, supra note 170 , at 23 (emphasis added).

172. See Joseph A. Grundfest \& MAX BeruefFy, The Treadway Commission Report: TwO YEARS LATER 4-7 (1989), https://www.sec.gov/news/speech/1989/o12689grundfest.pdf [https://perma.cc/LVV6-RBED].

1 73. Codification of ACCT. Standards \& Procs., Statement on Auditing Standards No. 99, $\S 4$ n.3 (AM. Inst. OF CERTIFIED Pub. ACCTS. 2002).

174. See supra text accompanying note 166.

175. Albrecht, supra note 7 , at 5 . Albrecht himself subsequently changed his own view on the "character" point: "Over time and through conducting many more research projects, I personally came to agree that Cressey's labeling of the third element as a way to rationalize the behavior as not being inconsistent with one's personal code of conduct was more accurate than our label of personal integrity." Id.

176. CoDification of ACCT. STANDARds \& Procs., Clarified Statements on Auditing Standards, AU-C § 240.A1 (AM. InST. OF CERTIFIED PUB. ACCTS. 2020); ISA 240, supra note 10, II A1. 
would commit the fraud must be of a character that would allow them to knowingly commit a dishonest, criminal act. ${ }^{177}$

In 1989, Loebbecke et al. published an article summarizing that model and applying it to the results of a survey of the audit partners of KPMG Peat Marwick. ${ }^{178}$ In this model, the third factor is "character," in line with Albrecht et al.'s identification of "personal integrity" and the AICPA's identification of "attitudes." 179

Thus, it appears that auditing standards, including those adopted by the AICPA in 2002, built upon various studies of the causes of fraud, including the work by Albrecht et al. and the Treadway Commission. That research had moved beyond Cressey's embezzlement-related factors. It is therefore not surprising that the fraud triangle factors in U.S. and international auditing standards differ from Cressey's factors.

\section{WhO COINED THE "FRAUD TRIANGLE" NAME?}

Even the origin of the term "fraud triangle" is disputed. Donald Cressey did not use it in his writings. ${ }^{180}$ One source says that Cressey "reputedly used the terminology in orally-delivered remarks," but it does not provide a citation. ${ }^{181}$ Morales et al. report that the AFCE stated in an email that Joseph Wells, its founder, originated the term with a triangle graphic he used in "a video featuring Dr. Cressey." ${ }^{82}$ However, Steve Albrecht, who used the term in a 1991 article, ${ }^{183}$ has argued that he was the one who labelled the three factors the "fraud triangle," after the "fire triangle," when an attendee at a

177. James K. Loebbecke, Martha M. Eining \& John J. Willingham, Auditors' Experience with Material Irregularities: Frequency, Nature, and Detectability, 9 AUdITING:J. PrAC. \& THEORY 1, 4 (1989) (emphasis added). Loebbecke, Eining, and Willingham argued that if any one of the three factors is not present, material management fraud will not occur. Id. at 5 fig. 1 .

178. Id. at 4-5, $15^{-19}$ tbl.9.

179. See supra text accompanying notes $143,166$.

180. Schuchter \& Levi, Beyond the Fraud Triangle, supra note 62, at 177 n.5.

181. Ryesky, supra note 7 , at 144 n.154.

182. See Morales et al., supra note 19, at 177. They explain:

We contacted the ACFE by email concerning the origins of this term and received the following response from an ACFE representative:

Dr. Cressey developed the three items, but he did not call it the Fraud Triangle. Actually, Dr. Wells is the first person we know of to take the three items and put [them] in a triangle format. He was working on a video featuring Dr. Cressey in $198_{5}$, and he used a triangle graphic in the video to illustrate the 3 factors that are present in most white-collar offenses. He began using the triangle graphic in training programs after that time. People saw the graphic and began referring to it as the Fraud Triangle over the years. So although we have never undertaken an extensive review of its use, as far as we know, that's how it came about.

Id. (alteration in original) (quoting E-mail from an ACFE representative (May 27, 2011 )).

183. W. Steve Albrecht, Fraud in Government Entities: The Perpetrators and the Types of Fraud, 7 GOV'T FIN. REV. 27, 27 (1991). 
seminar Albrecht gave at a paper company suggested that the two concepts are similar. ${ }^{184}$

The label "fraud triangle" makes more sense when applied to Albrecht's work than to Cressey's. Cressey focused on embezzlement and similar trust violations, ${ }^{185}$ while Albrecht and his co-authors studied the causes of fraud. ${ }^{186}$ Morales et al. observe that "Cressey (1953) does not stress the word 'fraud' in his book; the index indicates only one page in which 'fraudulent checks' is found, while 'embezzlement' is found on 24 pages." ${ }^{187}$

Some sources refer to it as "Cressey's fraud triangle" 188 or say that Cressey developed the fraud triangle to explain the causes of fraud. ${ }^{189}$ However, those sources overlook some of the relevant history. Cressey's study focused on embezzlement, and his three factors underwent revisions before they were reflected in auditing standards. ${ }^{19^{\circ}}$ It makes sense that the factors were given a name that refers to fraud after they were adapted to the fraud context.

184. Albrecht, supra note 7, at 5. Albrecht adds, "I even included quotation marks around the term because I hadn't heard it used before." Id. at 6 .

The fire analogy may have caused some confusion. On the one hand, Albrecht wrote in 1991:

The fraud triangle is very much like the "fire triangle." In order to have a fire, three conditions must exist: there must be oxygen, heat and fuel. If any one of these is removed, there will be no fire. Likewise with fraud: if either the pressure, opportunity or rationalization is removed, fraud does not occur.

Albrecht, supra note $18_{3}$, at 27 . This is consistent with Cressey's argument. See CRESSEY, OTHER PEOPLE'S MONEY, supra note 16 , at 139 ("[T] he absence of any of these [three] events will preclude violation."). On the other hand, Albrecht and his co-authors of the 1979 study found that even if two elements are missing, fraud could occur if the other element is strong enough. See Albrecht, supra note 7, at 4-5. Schuchter and Levi found in interviews that it was not necessary for all three elements to be present, and they "strongly suggest that a distinction must be made" between the mechanisms of the fraud triangle and the fire triangle. Schuchter \& Levi, Revisited, supra note 14 , at 109 .

185. See Huber, supra note $\mathbf{1 5}^{1}$, at $3^{1}$ (arguing that the fraud triangle should be renamed the "embezzlement triangle" and that it has no application to fraud).

186. See Albrecht, supra note 7, at 3 (stating that Cressey "never drew or referred to [the 3 elements] as a triangle nor used the term 'fraud triangle.' He also limited his discussion to embezzlement and not to fraud in general.").

187. Morales et al., supra note 19, at 176 (citation omitted). However, an article published prior to Cressey's book and discussing some of the same material was called Why Do Trusted Persons Commit Fraud?: A Social-Psychological Study of Defalcators. See Cressey, Trusted Persons, supra note 27.

188. See, e.g., John D. Gill, The Fraud Triangle on Trial, FrAUd MAG., Sept.-Oct. 201 7, at 18, 19 (stating in the abstract, "Dr. Donald Cressey's fraud triangle has endured"); P. Ravisankar, V. Ravi, G. Raghava Rao \& I. Bose, Detection of Financial Statement Fraud and Feature Selection Using Data Mining Techniques, 5o DECISION SUPPORT SYS., 491, 492 (2011) ("The fraud triangle is also known as Cressey's Triangle, or Cressey's Fraud Triangle.").

189. See, e.g., Rabi'u Abdullahi, Noorhayati Mansor \& Muhammad Shahir Nuhu, Fraud Triangle Theory and Fraud Diamond Theory: Understanding the Convergent and Divergent for Future Research, 12 EUR. J. BUS. \& MGMT. 30, 30 (2015) ("Cressey (1950) focused his research on the factors that lead individuals to engage in fraudulent and unethical activity."); Schuchter \& Levi, Revisited, supra note 14, at 107 ("This article revisits the Fraud Triangle, an explanatory framework for financial fraud, developed by the American criminologist Donald Cressey.").

19o. See Gregory M. Trompeter, Tina D. Carpenter, Naman Desai, Keith L. Jones \& Richard A. Riley, Jr., A Synthesis of Fraud-Related Research, 32 AUDITING: J. PRAC. \& THEORY, supp. 1, 2013, at 287,291 ("Although initially developed by Cressey (1950) to explain embezzlement, 


\section{ApPlying the Fraud Triangle to TAX Evasion}

Although the fraud triangle was developed in the context of certain types of malfeasance, its three factors-(1) an incentive or perceived (usually financial) pressure; (2) a perceived opportunity to cheat; and (3) rationalization of the planned action-could also apply to other kinds of fraudulent activity. For example, one article applied it to the Libor manipulation scandal. ${ }^{19^{1}}$ Steve Albrecht has argued that the fraud triangle can apply to any kind of "compromise." 192

While there are questions about how far the fraud triangle can extend, ${ }^{193}$ applying it as a lens on tax evasion is not a big stretch. First, tax evasion is a type of fraud. ${ }^{194}$ Second, the fraud triangle often focuses on an individual acting alone, although it has been extended to collusive activity. ${ }^{195}$ Tax evasion need not involve collusion. For example, it can occur in the context

researchers and regulators have expanded the fraud triangle model to incorporate fraudulent financial reporting. Consistent with this, they have broadened the language to include 'pressure' and 'incentive." (quoting CODIFICATION OF ACCT. STANDARDs \& Procs., Statement on Auditing Standards No. 99 (AM. INST. OF CERTIFIED PUB. ACCTS. 2002))).

191. See Mark Lokanan \& Satish Sharma, A Fraud Triangle Analysis of the Libor Fraud, $10 \mathrm{~J}$. FORENSIC \& INVESTIGATIVE ACCT. 187, 187 (2018). For a description of the Libor scandal, see James McBride, Understanding the Libor Scandal, COUNCIL ON FOREIGN RELS. (Oct. 12, 2016), https://www.cfr.org/backgrounder/understanding-libor-scandal [https://perma.cc/F7XB$4 \mathrm{~V} 2 \mathrm{~B}]$.

192. Albrecht, supra note 7, at 7 ("Whether it's fraud or any other type of compromise, the same three elements-perceived pressure, perceived opportunity and some way to rationalize the compromise as not being inconsistent with one's code of conduct-are always present.").

193. For example, Donegan and Ganon argued that "even if Cressey's findings for embezzlers were valid, there is little evidence to support the fraud triangle as a general theory of financial crime." Donegan \& Ganon, supra note 142, at 3. By contrast, Schucter and Levi, who found that their cases did not all fit Cressey's three-factor generalization, concluded that "the Fraud Triangle does not lose its importance; rather the coercive 'must be' for every element has to be replaced by 'can be' or 'almost always is.'” Schuchter \& Levi, Revisited, supra note 14, at 118. Although discussing these studies in detail is outside the scope of this Article, it is worth noting that several scholars have conducted empirical studies testing the three factors in the accounting standards as predictors of fraud. See, e.g., Lokanan \& Sharma, supra note 191, at 197-98; Yung-I Lou \& Ming-Long Wang, Fraud Risk Factor of the Fraud Triangle Assessing the Likelihood of Fraudulent Financial Reporting, J. BUS. \& ECON. RSCH., Feb. 2009, at 61, 61-62; Christopher J. Skousen, Kevin R. Smith \& Charlotte J. Wright, Detecting and Predicting Financial Statement Fraud: The Effectiveness of the Fraud Triangle and SAS No. 99, in 13 ADVANCES IN FINANCIAL ECONOMICS: CORPORATE GOVERNANCE AND FIRM PERFORMANCE 53-81 (Mark Hirschey et al. eds., 2009).

194. Emily Tuner, Chad Albrecht, Conan Albrecht \& Victor Morales Rocha, A Historical View of the Walter Anderson Tax Evasion Scheme, J. TAX'N, May 2018, at 7, 7 ("Fraud has often been described as the process of using dishonest methods to take, or misrepresent, something of value, often money or other resources, from another person or organization. Under this definition, tax evasion is a particular type of fraud involving the illegal nonpayment or underpayment of tax." (footnote omitted)); Doreen McBarnet, Whiter than White Collar Crime: Tax, Fraud Insurance and the Management of Stigma, 42 BRIT. J. SOCIO. 323, 323 (1991) ("Tax evasion is a term usually reserved for non-payment of tax by means of criminal fraud or other violations of law.").

195. Free, supra note 4 , at $18_{5}$. Free observes that "the major frauds of recent decades, including Enron, WorldCom, Parmalat, HealthSouth and Satyam, all illustrate that collusion is a central element in many complex and costly frauds and financial crimes." Id. 
of an individual self-preparing an annual tax return or lying to a tax preparer. ${ }^{196}$

Third, the origins of the fraud triangle lie in studies of embezzlers. Tax fraud is not identical to embezzlement, as the funds a taxpayer receives may begin as one's own (e.g., as payment for services or property), rather than in trust for another party, but the two concepts share the central aspect of conversion of funds that rightfully belong to another. ${ }^{197}$ Cressey actually used tax evasion as the opening example in an article focusing primarily on embezzlement. ${ }^{198}$ The fraud triangle has also evolved to encompass frauds that are further removed from embezzlement, such as financial statement fraud, which entails fraud on behalf of a third-party organization.

Although a handful of scholars have applied the fraud triangle to tax fraud, generally in brief treatments, ${ }^{199}$ the legal literature on tax compliance and evasion generally does not mention the fraud triangle. A short article in

196. Tax preparers can also collude in tax evasion, though that behavior likely occurs only in a small part of the tax preparer market. See Susan Cleary Morse, Stewart Karlinsky \& Joseph Bankman, Cash Businesses and Tax Evasion, 20 STAN. L. \& POL'Y REV. 37, 59 (2009) ("The majority of cash business preparers were people like B [an anonymous accountant], who suspected his clients of tax evasion and refused to help his clients cheat, but did not investigate further or make serious attempt to limit the cheating. A much smaller set of preparers seemed to go much farther and actively assist tax evasion.”). Some tax preparers may simply avoid asking about things such as "cash income, so as to permit the tax preparer to avoid the uncomfortable question of whether to participate in what is plainly an evasion scheme." Id. at 43 .

197. One article argued that "[i]n most situations, tax evasion can be viewed as embezzlement of government funds. The fraud triangle is particularly applicable to embezzlement because Cressey's original study used embezzlers as subjects.” James A. Tackett, Joe Antenucci \& Fran Wolf, A Criminological Perspective of Tax Evasion, 110 TAX NOTEs 654, 655 (2006).

198. See Cressey, Respectable Criminal, supra note 24, at 13 (opening the article as follows: "Spring has returned, and with it two of the major themes of strategy in American life-how to win a baseball pennant and how to beat the income tax collector.").

199. See, e.g., Dorminey et al., Evolution of Fraud Theory, supra note 32 , at $56_{3}$ (mentioning tax evasion as an example); Todd Haugh, Overcriminalization's New Harm Paradigm, 68 VAND. L. REV. 1191,1226 (2015) (discussing as an example "one of Cressey's 'respectable' criminals: the tax cheat," but not using the term "fraud triangle"); Michael Pickhardt \& Aloys Prinz, Behavioral Dynamics of Tax Evasion-A Survey, J. ECON. PSYCH., Feb. 2014, at 1, 12 (combining "Cressey's (1953) 'fraud triangle' ... with the Mazar et al. (2008) and Ariely (2012) approach which is called here 'fudge triangle"); Grant Richardson, Grantley Taylor \& Christopher S. Wright, Corporate Profiling of Tax-Malfeasance: A Theoretical and Empirical Assessment of Tax-Audited Australian Firms, 12 EJOURNAL TAX RSCH. 359 (2014) (applying the fraud triangle to a set of Australian firms' tax reporting to identify badges of tax malfeasance); Tackett et al., supra note 197 (discussing the criminology of tax evaders using the fraud triangle approach); Tuner et al., supra note 194 , at 7 (applying the fraud triangle primarily to a specific tax evasion case). None of the authors of these articles appear to be on law faculties. Most appear to be business school or accounting professors.

The author of this Article also authored a blog post applying to tax evasion both the fraud triangle and the four-factor version called the fraud diamond. See generally Leandra Lederman, Tax Evasion and the Fraud Diamond, Surly SubGroup (Dec. 18, 2018), https:// surlysubgroup.com/2018/12/18/tax-evasion-and-the-fraud-diamond [https://perma.cc/F $3 \mathrm{FM}$ -HKMV]. 
Tax Notes authored by three CPAs engages in perhaps the most comprehensive application of the fraud triangle's three factors to tax evasion. ${ }^{200}$

In that article, Tackett et al. briefly apply each factor to tax evasion. They label the first factor only as pressure - not incentive-and they explain that someone may feel financial pressure regarding the tax liability. ${ }^{201}$ They further argue that the costs of complying with the tax laws may cause psychological pressure and additional financial pressure. ${ }^{202}$ They briefly discuss the second element (opportunity), using a metaphor of a department store that functions on the honor system-implying, as discussed below, ${ }^{203}$ that lack of monitoring and sanctions for wrongdoing would soon put the store out of business. ${ }^{20}$ With respect to the third factor (rationalization), Tackett et al. provide three possible types of rationalizations for tax evasion. ${ }^{205}$ Each of the three elements of the fraud triangle also has additional aspects when applied to tax evasion, and is examined, in turn, below.

\section{A. FinanCIAL PRESSURE OR INCENTIVE}

Financial pressure and incentive are two distinct possible motivators for tax evasion. Financial pressure that can be relieved by tax evasion can occur in a variety of contexts. One such context involves small businesses. A business owner who employs workers is required to withhold income and employment taxes from the employees' paychecks and remit those taxes to the government. ${ }^{206}$ Under the Internal Revenue Code, these taxes are "held to be a special fund in trust for the United States." ${ }^{207}$ It is well known that struggling small businesses may fail to remit these "trust fund taxes." ${ }_{208}$ This is

20o. See generally Tackett et al., supra note 197 (using the fraud triangle as a focal point for arguing that its framework helps better identify possible tax evaders).

201. Id. at 655 .

202. Id. at $655^{-} 5^{6}$.

203. See infra text accompanying notes 292-93 (critiquing the "honor system" metaphor).

204. Tackett et al., supra note 197 , at $6_{5} 6$ (discussing the "opportunity" element in two paragraphs, referring to "a department store operat[ing] on the honor system ... without any supervision other than a 1 percent chance of being audited," with almost no likelihood of prosecution and only a small fine if caught, and positing: "How long would such a store remain in business? The scenario is analogous to the federal income tax system.”).

205. See id.

206. I.R.C. $\$ \S 3101-3102$ (2018) (employment taxes); id. $§ \S 3402-3403$ (income taxes).

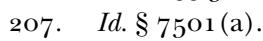

208. Lawrence J. Gregory, Trust Fund Taxes: Personal Liability for Small Business Owners in Economic Decline, 25 DCBA BRIEF, Nov. 2012, at 16, 17 ("A small business may be suffering for some time.... [O]wners may stop remitting employment tax withholding as a way to free up some extra cash, paying their suppliers instead."); see U.S. GEN. ACCT. OFF., GAO-O2-92, TAX ADMINISTRATION: IRS'S EFFORTS TO IMPROVE COMPLIANCE WITH EMPLOYMENT TAX REQUIREMENTS SHOUlD BE EVALUATED 1 (2002) ("When confronted with a choice between paying necessary operating expenses or depositing employment taxes, struggling businesses may opt to pay business expenses instead of taxes.”); Am. Bar Ass'n Comm'n on Taxpayer Compliance, Report and Recommendations on Taxpayer Compliance, 41 TAX LAW. 329, 367 (1987) ("It is tempting for the business owner in such desperate straits to view employee tax withholdings as an interest-free loan that will be paid back once business turns around.”); T. Keith Fogg, In Whom We Trust, 43 
closely analogous to embezzlement and similar violations of financial trust. ${ }^{209}$ The "financial pressure" element of the fraud triangle may help explain why a business owner could operate for a long time properly remitting trust fund taxes but begin to convert those funds for the business's use when faced with financial difficulties that threaten the business's existence.

Trust fund tax enforcement is distinct and carries a special tax penalty. ${ }^{210}$ A better-known tax compliance context involves an individual preparing an annual return. ${ }^{211} \mathrm{~A}$ taxpayer who owes tax but is facing financial pressures could be inclined to cheat so as to reduce the amount owed or produce a larger tax refund. This may or may not involve a tax preparer. ${ }^{212}$ The tax liability itself can also create financial pressure. ${ }^{213}$

Even absent financial pressure, the lure of saving money provides an incentive to cheat. For example, in the annual return-preparation context, even if an individual faces no special external financial pressure, and even if the tax liability itself does not create pressure (e.g., because the taxpayer is due a tax refund), the possibility of being able to pocket extra money does provide a financial incentive. ${ }^{214}$

In the corporate context, "[d] eclaring large profits-and even better, large after-tax profits-is often viewed as a signal of superior performance." ${ }^{215}$ The corporation's owners are the direct beneficiaries of a reduction in tax

CREIGHTON L. REV. 357, 361 (2010) ("Non-compliance with payment of collected taxes generally occurs with small businesses and not with large ones. . . The failure rate of these businesses is high ... The federal tax obligation that impacts them most is the employment tax liability ...." (footnotes omitted)).

209. Leandra Lederman, Tax Compliance and the Reformed IRS, $5^{1}$ U. KAN. L. REV. 971,1006 $-\mathrm{O} 7$ (2003) [hereinafter Lederman, Reformed IRS] ("Often it is failing businesses that do not pay over the taxes, essentially embezzling them as a way to forestall closing down.").

210. See I.R.C. $\$ 6672$ (a) ("Any person required to collect, truthfully account for, and pay over any tax imposed by this title who willfully fails to collect such tax, or truthfully account for and pay over such tax, or willfully attempts in any manner to evade or defeat any such tax or the payment thereof, shall, in addition to other penalties provided by law, be liable to a penalty equal to the total amount of the tax evaded, or not collected, or not accounted for and paid over.").

211. Some individuals also are required to make quarterly estimated tax payments. See IRS, INTERNAL REVENUE SERVICE DATA BOOK, 2017 , at 4 tbl.2 (2018), https://www.irs.gov/pub/irssoi/1 7 databk.pdf [https://perma.cc/ $2 \mathrm{DRZ}-37 \mathrm{VF}$ ] (showing that in 2017, 22,230,026 estimated income tax returns were filed).

212. See supra note 196 and accompanying text.

213. See Tackett et al., supra note 197 , at $6_{5} 6$ ("[T] he pressure element of the fraud triangle in tax evasion consists of the financial pressure of paying the tax along with the financial and psychological pressure (that is, resentment) of compliance with the tax laws.").

214. Cf. Jerry L. Mills, What to Do When the Boss Is a Tax Evader, CFO (Aug. 25, 2014), https:// www.cfo.com/tax/2014/o8/boss-tax-evader [https://perma.cc/PG 4 X-V6gL] ("The higher the effective tax burden, the more is the temptation . . . for business owners to use aggressive methods to lower their tax payments.”).

215. Graeme S. Cooper, Analyzing Corporate Tax Evasion, 5o TAX L. REV. 33, 75 (1994). 
liability. ${ }^{216}$ This may, in turn, translate to pressure on employees. ${ }^{217}$ In the context of legal tax avoidance, Mihir Desai and Dhammika Dharmapala argue, " $[\mathrm{e}]$ ssentially, shareholders want managers to avoid taxes, and managers, once their incentives are sufficiently aligned, engage in tax avoidance." 218 Incentives may become aligned through incentive-based compensation. ${ }^{219}$ For example, "[t]o align incentives, it may be appropriate for the tax officer's salary to depend (inversely) on the effective tax rate achieved." ${ }^{220}$

Corporate tax reduction may not stop with legal tax avoidance strategies.

Both avoidance and evasion are rooted in the same desire-to minimize the corporation's total tax liability, not at all costs, but up to the point where the marginal costs of additional efforts to reduce the tax liability equal the marginal tax saving.

216. Id. at 77 ("It is in the shareholders' interests for the managers to seek to reduce the size and number of competing claimants (such as the revenue authority) on the corporation's assets.”); Michelle Hanlon \& Joel Slemrod, What Does Tax Aggressiveness Signal? Evidence from Stock Price Reactions to News About Tax Shelter Involvement, 93 J. PUB. ECON. 126, 126 (2009) ("[I]n order to maximize the value of the firm, shareholders would like to minimize corporate tax payments net of the private costs of doing so ....").

217. See Keith J. Crocker \& Joel Slemrod, Corporate Tax Evasion with Agency Costs, 89 J. PuB. ECON. 1593, 1595 (2005) (stating, in 2005, that " $[\mathrm{t}]$ here [wa]s abundant evidence that the focus of corporate tax departments has changed from that of passive compliance with the tax laws to active, aggressive, and often arguably illegal tax planning"); $i d$. ("Of the various measures used to evaluate the performance of tax departments, the most often cited was the savings, or value added, they provided: $86 \%$ cited this performance measure ... Of those $86 \%, 63 \%$ said that this measure affected the compensation of tax department personnel.”).

The employees may also be shareholders, in which case they directly benefit from an increase in the value of the corporation:

[T] he apparent divergence between owners and managers may not be significant where the corporation's managers have already become the partial owners of the corporation... The paradigm example is the privately held corporation where there is little separation of ownership from management. But even in publicly held corporations, it is common for the remuneration of the corporation's managers to be tied to their efforts to enhance the market value of the corporation through share and option allotment schemes.

Cooper, supra note 215 , at 80 .

218. Mihir A. Desai \& Dhammika Dharmapala, Earnings Management, Corporate Tax Shelters, and Book-Tax Alignment, 62 NAT'L TAX J. 169, 171 (2009).

219. Sonja Olhoft Rego \& Ryan Wilson, Equity Risk Incentives and Corporate Tax Aggressiveness, $5^{\circ}$ J. ACCT. RSCH. 775, 779 (2012) (“[R]isk-averse managers must be properly incentivized to undertake risky tax strategies that generate net benefits for the firm and its shareholders. Our results suggest that equity risk incentives provide managers such incentives."); see also Mihir A. Desai \& Dhammika Dharmapala, Corporate Tax Avoidance and High-Powered Incentives, 79 J. FIN. ECON. 145, 149 (2006) ("The tremendous growth in incentive compensation during the 199 os coincided with an increased disconnect between the profits reported to capital markets and the profits reported to tax authorities."); $c f$. Dorminey et al., Enhancing Deterrence, supra note 15, at 21 ("With financial reporting fraud, the first leg of the fraud triangle has been adjusted from pressure to focus on motivators such as monetary incentives, bonuses, or stock options.").

220. Crocker \& Slemrod, supra note 217 , at 1595 . 
... At some point it is quite conceivable that the corporation's

managers will substitute evasion for further avoidance $\ldots .^{221}$

More generally, "managers may be prepared to engage in evasion because they have been effectively motivated to further the shareholders' interests, or because they believe evasion will further their own interests." 222

Of course, corporate tax evasion, which is illegal, has costs, including risks to employees. One such risk is possible criminal sanctions: "Corporate managers might be implicated in such offenses as attempting to evade the corporate tax, aiding or abetting tax evasion by the corporation, conspiring to defraud the government through tax evasion, failing to file tax returns, or making false statements to the revenue authority in tax returns.”223 However, employees may disregard this risk if they believe that the likelihood that tax fraud will result in personal or criminal liability is incredibly small. ${ }^{224}$

Another risk to employees is possible termination of employment if the government detects the evasion. ${ }^{225}$ However, employees may believe that it is unlikely that tax fraud will be detected. ${ }^{226}$ Moreover, "[a]lthough termination is a serious penalty, the threat of job loss provides limited deterrence when the individual deciding whether to commit fraud believes that her job is on the line anyway." 227 In short, if the pressures on corporate employees and/or financial incentives outweigh the expected costs, that dynamic can prompt tax evasion, even if the incentive structure was not intentionally designed for that purpose. ${ }^{228}$

Thus, incentives and pressures can both be factors in tax fraud. The evolution of the first factor in Cressey's research to the fraud triangle's

\footnotetext{
221. Cooper, supra note 215 , at $87-88$.

222. Id. at 79-80.

223. Graeme S. Cooper, The Return to Corporate Tax Evasion in the Presence of an Income Tax on Shareholders, 12 AKRON TAX J. 1, 8-9 (1996) (footnotes omitted).
}

224. Id. at 9 (stating that a corporate manager might "belie[ve] that the imposition of personal liability is so unlikely that he may treat the prospect of punishment as negligible"); Cooper, supra note 215 , at 83 ("Administrative practices, preferring the imposition of civil fines on the corporation to prosecution of individuals for fraud, may support this perception that evasion carries no real threat of individual punishment.").

225. See Urska Velikonja, Leverage, Sanctions, and Deterrence of Accounting Fraud, 44 U.C. DAVIS L. REV. 1281, 1299 (2011) (stating that employees "caught [committing fraud] might lose their job (e.g., nine out of ten managers named in SEC or Department of Justice ('DOJ') enforcement actions for fraud did indeed lose their jobs)").

226. See Cooper, supra note 215 , at 96 ("It is possible that evasion will not be detected, especially if steps are taken by the corporation to conceal its behavior; [and] some detected errors will be 'deniable' in the sense that they may be successfully represented as innocent mistakes or avoidance ...."); Velikonja, supra note 225, at 1299 ("[N]ot all fraud is discovered, and not all discovered fraud is subject to an enforcement action.").

227. Velikonja, supra note 225, at 1299-13oo.

228. Cooper, supra note 215 , at 79 (" $[\mathrm{I}] \mathrm{t}$ may be that the shareholders have introduced incentive structures ... which, although implemented for more general purposes, are effective to overcome the managers' reluctance to become involved in evasion."); see also Crocker \& Slemrod, supra note 217 , at 1594 ("The incentives of the CFO to engage in tax evasion are affected by the nature of her compensation arrangement."). 
"pressure or incentive" helps expand the scope of the fraud triangle to the various contexts in which tax evasion may occur.

\section{B. PERCEIVED OPPORTUNITY TO EVADE}

The second, and most constant, fraud triangle factor is "perceived opportunity," sometimes just referred to as "opportunity." 229 Tackett et al. remark that "[i]f opportunity is not present, fraud is impossible." ${ }_{230}$ Morales et al. stated about Cressey's concept of opportunity, “[o]f [Cressey's] three conditions, the most evident (to the point where it may seem tautological) is that of perceived opportunity: if a person commits an act, then he or she must necessarily have perceived the possibility to do so." ${ }^{23^{1}}$ The same holds for tax evasion. That is, tax evasion necessarily involves some kind of perceived opportunity to evade.

In the individual income tax context, some taxpayers have more opportunity to evade taxes than others. For example, it is easier to successfully evade taxes with respect to cash income than with respect to items that have a paper trail. ${ }^{232}$ Accordingly, the opportunity to evade can be reduced through the use of third-party reporting of taxes, such as on Form W-2 or 1099, and/or withholding, such as occurs in the employment context. ${ }^{233}$

Withholding involves retention of a tax amount before it is ever paid to the taxpayer, decreasing the taxpayer's opportunity to avoid paying it over²34

229. See, e.g., Tackett et al., supra note 197 , at 655 ("The fraud triangle hypothesizes that three elements are generally present when fraud occurs. Those elements are pressure, opportunity, and rationalization.").

230. Id.

231. Morales et al., supra note 19, at 175; cf. Schuchter \& Levi, Beyond the Fraud Triangle, supra note 62 , at 184 ("Contrary to findings in the literature and the previously mentioned international fraud standards, we found that only opportunity is (perhaps tautologically) mandatory for committing a white-collar crime, according to our interviewed offenders.").

232. See, e.g., Dina Pomeranz, No Taxation Without Information: Deterrence and Self-Enforcement in the Value Added Tax, 105 AM. ECON. REV. 2539, 2540 (2015) (finding evidence in a study of Chilean VAT enforcement that a paper trail deters tax evasion); Kathleen DeLaney Thomas, UserFriendly Taxpaying, 92 IND. L.J. 1509, 1534 (2017) ("The most obvious upside of information reporting is the clear deterrence benefit: income that is reported to the IRS by third parties is all but impossible for taxpayers to conceal without detection."); Morse et al., supra note 196, at 37 ("Underpayment of tax on business income is commonly attributed to the receipt of cash.").

233. See generally Leandra Lederman \& Joseph C. Dugan, Information Matters in Tax Enforcement, 2020 BYU L. REV. 145 (analyzing the importance of third-party reporting).

234. The taxpayer whose taxes were withheld could still cheat on the tax return with respect to the income subject to withholding or with respect to other items. However, the paper trail accompanying the withheld amounts reduces the opportunity to cheat. IRS statistics show a 99 percent compliance rate with respect to items subject to information reporting and withholding (that is, wages and salaries). IRS, PUB. $14^{1} 5$ (REV. 5-2016), FEDERAL TAX COMPLIANCE RESEARCH: TAX GAP ESTIMATES FOR TAX YEARS 2008-2010, at 12 chart 1 (2016) [hereinafter IRS, TAX GAP ESTIMATES FOR TAX YEARS 2008-2010], https://www.irs.gov/pub/irs-soi/p1415.pdf [https:// perma.cc/MU85-JQ64]. With respect to other amounts, cash income generally faces the most evasion. A taxpayer with only wage income could invent deductions or credits, but those involve affirmatively including items on the return, rather than omitting an item. Taxpayers may be less likely to affirmatively lie than to lie by omission. See Jay A. Soled \& Kathleen DeLaney Thomas, Regulating Tax Return Preparation, 58 B.C. L. REV. 152, 196-97 (2017) ("As various psychological 
(but increasing the opportunity for the withholding agent to abscond with it).235 Third-party reporting involves a paper trail that makes the payment visible to the tax authority: Both the tax administration and the taxpayer receive an information report containing the amount paid and other information, including the amount of any tax withheld. ${ }^{23}{ }^{6}$ The taxpayer could omit from the return the amount included in the information report, but simple document matching would likely detect it.237 That obvious transparency should deter tax evasion. And, in fact, IRS statistics support the intuitive notion that, as the information the IRS has about an income item decreases, voluntary compliance also decreases:

\begin{tabular}{|c|c|}
\hline Type of Income & $\begin{array}{c}\text { Estimated Voluntary } \\
\text { Compliance Rate }{ }^{38}\end{array}$ \\
\hline $\begin{array}{c}\text { "Income subject to substantial information } \\
\text { reporting and withholding" }\end{array}$ & $99 \%$ \\
\hline $\begin{array}{c}\text { "Income subject to substantial information } \\
\text { reporting" }\end{array}$ & $95 \%$ \\
\hline $\begin{array}{c}\text { "Income subject to some information } \\
\text { reporting" }\end{array}$ & $83 \%$ \\
\hline $\begin{array}{c}\text { "Income subject to little or no information } \\
\text { reporting" }\end{array}$ & $45 \%$ \\
\hline
\end{tabular}

The relationships among these figures have been consistent over time. ${ }^{239}$ The IRS has therefore observed that "[f]or the individual income tax,

studies confirm, an act of omission (like failing to report income) costs individuals very little mental energy compared to an act of commission (like robbing a bank) . . . Forcing taxpayers to affirmatively lie on their return if they want to omit tax obligations should make them more reluctant to do so and thereby increase compliance." (footnotes omitted)). Items listed on the return are also easier for the IRS to audit. See Colony, Inc. v. Comm'r, 357 U.S. 28, 36 (1958) (explaining, in the context of an extended statute of limitations, that "a taxpayer's omission to report some taxable item[] [puts] the Commissioner . . . at a special disadvantage in detecting errors").

235. The withheld taxes constitute "trust fund taxes" that the withholding agent could fail to pay over. This issue is discussed in supra text accompanying notes $205^{-09}$.

236. See Leandra Lederman, Statutory Speed Bumps: The Roles Third Parties Play in Tax Compliance, 6o STAN. L. REV. 695, 697 (2007) [hereinafter Lederman, Statutory Speed Bumps]. This also simplifies compliance for the taxpayer. Thomas, supra note 232, at 1534 ("An enormous advantage of information reporting for taxpayers is that it is essentially equivalent to recordkeeping by the third parties that report the income.").

237. Jim Buttonow, The New IRS “Audit": Upfront Information-Statement Matching, H\&R BLOCK (May 17, 2017), https://www.hrblock.com/tax-center/newsroom/irs/upfront-informationstatement-matching [https://perma.cc/78ZZ-UHWH].

238. See IRS, Pub. 1415 (Rev. 9-2019), Federal Tax Compliance Research: Tax Gap ESTIMATES FOR TAX YEARS $2011-2013$, at 14 fig.3 (2019) [hereinafter IRS, TAX GAP ESTIMATES FOR TAX YEARS 2011-2013], https://www.irs.gov/pub/irs-pdf/p1415.pdf [https://perma.cc/C7LFK753] (showing noncompliance rates).

239. Compare, e.g., IRS, TAX GAP ESTIMATES FOR TAX YEARS 2008-2010, supra note 234, at 12 chart 1 (showing estimated noncompliance rates for the categories of income in the table above, which translate to voluntary compliance rates of $99 \%, 93 \%, 81 \%$, and $37 \%$ ), with IRS, TAX GAP FOR TAX YEAR 2006, at 3 chart 1 (2012), https://www.irs.gov/pub/newsroom/overview_tax_ 
reporting compliance is far higher when income items are subject to information reporting and even higher when also subject to withholding." ${ }_{24} \mathrm{o}$

Although these IRS statistics do not prove causation, empirical studies of the question generally have found that third-party information reporting increases reporting of income. ${ }^{24^{1}}$ Thus, opportunity is a critical factor in tax noncompliance, just as it is in the fraud triangle.

\section{RATIONALIZATION}

The fraud triangle's third factor is "rationalization." Cressey explained that:

$[\mathrm{T}]$ he potential trust violator ... defines the relationship between the non-shareable problem and the illegal solution in language which enables him to look upon trust violation (a) as essentially noncriminal, (b) as justified, or (c) as a part of a general irresponsibility for which he is not completely accountable. ${ }^{2} 4^{2}$

Scholars have developed typologies of rationalizations, synthesizing decades of prior research that, aside from Cressey's work, took off with a 1957 article by Gresham Sykes and David Matza on juvenile delinquents. ${ }^{243}$ Sykes and Matza set forth what has since been termed the "Famous Five Neutralizations" that they found offenders used to rationalize their actions. ${ }^{244}$ Since then,

gap_20o6.pdf [https://perma.cc/ST82-HR8E] (reflecting estimated voluntary compliance rates of $99 \%, 92 \%, 89 \%$, and $44 \%)$.

240. IRS, TAX GAP ESTIMATES FOR TAX YEARS 2011-2013, supra note 238, at 13 .

241. See, e.g., Todd Kumler, Eric Verhoogen \& Judith A. Frías, Enlisting Employees in Improving Payroll-Tax Compliance: Evidence from Mexico 21-22 (Nat'l Bureau of Econ. Rsch., Working Paper No. 19385, 2013), http://www.nber.org/papers/w19385.pdf [https://perma.cc/2XLT-MLCM] (finding that a pension reform in Mexico that linked younger workers' pensions more closely to reported wages and allowed those workers to monitor their reported wages reduced firms' payroll tax evasion with respect to younger workers); Joana Naritomi, Consumers as Tax Auditors, 1 o9 AM. ECON. REV. 3031, 3052, 3069-70 (2019) (finding that the implementation of a "receipt lottery" and online access for consumers to check reported amounts increased São Paulo, Brazil retailers' reported revenues by at least 21 percent over four years); Junmin Wan, The Incentive to Declare Taxes and Tax Revenue: The Lottery Receipt Experiment in China, 14 REV. DEV. ECON. 611,617 (2010) (finding that the introduction of a receipt lottery in certain Chinese provinces increased retailers' sales tax payments in those provinces by $21.5^{-24.2}$ percent).

242. Cressey, Other PeOPle's Money, supra note 16 , at 93 .

243. Gresham M. Sykes \& David Matza, Techniques of Neutralization: A Theory of Delinquency, 22 AM. SociO. REV. 664, 667-69 (1957); see Shadd Maruna \& Heith Copes, What Have We Learned from Five Decades of Neutralization Research?, in 32 CRIME \& JUSTICE 221,222 (Michael Tonry ed., 2005 ) ("The study of offender verbalizations as 'data' in criminology might have originated with Cressey's (1953) study of embezzlers' excuses, but it has since become associated primarily with Gresham Sykes and David Matza's (1957) article, 'Techniques of Neutralization: A Theory of Delinquency."); $i d$. at 223 ("[S]omewhat oddly for a theory based on juvenile delinquency, [neutralization theory] has found its most receptive audience in studies of organizational and white-collar crime.").

244. Maruna \& Copes, supra note 243, at 231. These five neutralizations are "denial of responsibility, denial of injury, denial of the victim, condemnation of condemners, and the appeal to higher loyalties." Id. They are explained in more detail below. 
other scholars have expanded on that list.245 For example, in 2003, Blake Ashforth and Vikas Anand added three more rationalization techniques to the list. ${ }^{2} 4^{6}$

In 2004, Anand et al. reduced Ashforth and Anand's expanded list to "six tactics that [they] believe are most commonly used in organizations" as justifications for corrupt behavior. ${ }^{247}$ These factors are: (1) "Denial of responsibility" ("The actors engaged in corrupt behaviors perceive that they have no other choice than to participate in such activities."); (2) "Denial of injury" ("The actors are convinced that no one is harmed by their actions; hence the actions are not really corrupt."); (3) "Denial of victim" ("The actors counter any blame for their actions by arguing that the violated party deserved whatever happened."); (4) "Social weighting" ("The actors assume two practices that moderate the salience of corrupt behaviors: 1. Condemn the condemner, 2. Selective social comparison."); (5) "Appeal to higher loyalties" ("The actors argue that their violation of norms is due to their attempt to realize a higher-order value."); and (6) "Metaphor of the ledger" ("The actors rationalize that they are entitled to indulge in deviant behaviors because of their accrued credits (time and effort) in their jobs."). ${ }^{24}{ }^{8}$

Rationalizations can certainly come into play in the tax context. For example, the owner of a failing business who fails to pay over "trust fund taxes" could rationalize that this is the only way to save the business-which will help employees keep their jobs and will give rise to increased tax payments in the future from both the employees and the business once it is successful again. This is an example of an "appeal to higher loyalties" in the terminology of

245. Id. ("The subsequent expansion of the theory to different types of offenders and offenses has led to the 'discovery' of several new neutralization techniques. Schönbach (1990) devoted nearly an entire book to cataloging the different accounts that individuals offer for their actions.”).

246. Blake E. Ashforth \& Vikas Anand, The Normalization of Corruption in Organizations, 25 RSCH. ORganizational BeHAV. 1, 17 (2003) ("There appear to be at least eight types of rationalizations, five of which . . . were identified by Sykes and Matza (1957)." (citation omitted)).

247. Vikas Anand, Blake E. Ashforth \& Mahendra Joshi, Business as Usual: The Acceptance and Perpetuation of Corruption in Organizations, 19 ACAD. MGMT. ExEC., Nov. 2005, at 9, 11.

248. Id. at 11 tbl.1. The Anand et al. article also discusses each rationalization in more detail under a subheading named for the rationalization. See id. at 11-14.

For more recent work discussing most of these rationalizations, along with "Claim of Entitlement" and "Claim of Relative Acceptability/Normality," see, for example, Todd Haugh, The Criminalization of Compliance, 92 NOTRE DAME L. REV. 1215 , 1255-59 (2017) (discussing "eight of the most prominent rationalizations used by white collar and corporate offenders"); Haugh, supra note 199, at 1218-22 (exploring "eight of the most prominent rationalizations used by white collar criminals"); and Todd Haugh, Sentencing the Why of White Collar Crime, 82 FORDHAM L. REV. 3143, 3165-69 (2014) ("identif[ying] eight neutralization techniques employed by white collar criminals"). 
Anand et al. ${ }^{249}$ The owner could also rationalize that the nonpayment is only a "loan" that will soon be repaid..$^{2}{ }^{\circ}$ This is an example of "denial of injury." ${ }_{25}$

In the individual income tax context, Tackett et al. argue that " $[\mathrm{t}] \mathrm{he}$ overwhelming rationalization used in tax evasion is the lack of equity in the tax system. The lack of equity rationalization manifests itself along three dimensions: uneven tax burden, fiscal irresponsibility by the government, and lack of enforcement." ${ }^{25^{2}}$ That is, Tackett et al. argue that taxpayers may rationalize that (1) they are making up for tax breaks that others (e.g., the rich) get; (2) "governmental misspending or corruption justifies cheating on tax payments"; and (3) "[t]he lack of enforcement of the tax laws places an unfair burden on honest taxpayers." 253 These categories of rationalizations might be paraphrased as (1) self help (creating one's own tax break); (2) an eye for an eye (a response to perceived governmental misspending or other inadequacies); and (3) refusal to be a chump (because cheaters are routinely not caught, the compliant pay more than everyone else).

The first type of rationalization, self help, focuses on the idea that others, particularly the rich, have access to tax shelters and tax breaks that the rationalizer does not. That rationalization may be fueled by stories about loopholes exploited by the well-advised. ${ }^{254}$ This appears to be an example of "social weighting" in the terminology of Anand et al. ${ }^{255}$

The second type of rationalization-the eye-for-an-eye approach, which justifies evasion by pointing to government wastefulness or corruption-is a form of quid pro quo. In the typology of Anand et al., this falls within "denial of victim," which can take the form of the classic justification, "[ $\mathrm{t}]$ hey deserved it." ${ }_{25}{ }^{6}$ This type of justification may be used by illegal tax protestors. ${ }^{257}$

The third form of rationalization is refusal to be the only "chump" who is honest. In this regard, Tackett et al. argue:

249. See Anand et al., supra note 247, at 11 tbl.1 (giving as example rationalization of this type: "We answered to a more important cause.").

250. See Am. Bar Ass'n Comm'n on Taxpayer Compliance, supra note 208, at 367 ("It is tempting for the business owner in such desperate straits to view employee tax withholdings as an interest-free loan that will be paid back once business turns around.").

251. See Anand et al., supra note 247, at 11 tbl.1 (giving as example rationalization of this type: "No one was really harmed.").

252. Tackett et al., supra note 197 , at $65^{6}$.

253. Id.

254. For an example of this type of news story, see Emily Stewart, America's Getting $\$$ Io Trillion in Tax Cuts, and $20 \%$ of Them Are Going the Richest I \%, VOX (July 1 1, 2018, 11:50 AM), https:// www.vox.com/policy-and-politics/2018/7/11/17560704/tax-cuts-rich-san-francisco-fed.

255. See Anand et al., supra note 247, at 11 tbl.1 (giving as an example rationalization: "Others are worse than we are.").

256 . Id.

257. See Danshera Cords, Tax Protestors and Penalties: Ensuring Perceived Fairness and Mitigating Systemic Costs, 2005 BYU L. REV. 1515, $15^{18}$ ("Individuals who are dissatisfied with the government and its policies are more likely to be convinced that the tax system is illegitimate than are individuals who are satisfied with the government and its policies."). 
Many individuals believe (correctly) that tax evasion is widespread and goes unpunished in the vast majority of cases. The lack of enforcement of the tax laws places an unfair burden on honest taxpayers. Accordingly, tax evaders reason that evasion is their only option to obtain relief from an unjust tax system. ${ }^{25}$

This also may be a form of "social weighting," 259 but it focuses on the zero-sum game aspect of taxpaying because evading taxes raises the tax cost for everyone else. The "chump" rationalization highlights the importance of enforcement of the tax laws to sustaining norms of tax compliance. ${ }^{260}$ In other words, non-enforcement "sends a signal . . . that others do not wish to enforce the tax laws and that tax evasion is in some sense socially acceptable, and the social norm of compliance disappears." ${ }_{261}$

Taxpayers may use other rationalizations, as well. For example, they may rationalize that they need the money more than the government, that the government will never miss the money, or that they overpaid in a previous year and this will right that wrong. Whatever the rationalization, applying this fraud triangle element to tax evasion is helpful in understanding the dynamics of tax evasion.

\section{Potential Implications For TAX Compliance Models}

As noted at the beginning of this Article, the traditional economic model of tax compliance is the deterrence model, while, more recently, the literature has considered behavioral explanations for compliance. ${ }^{262}$ Some scholars have suggested that these theories are in tension with each other. ${ }^{263}$ Yet, there

$25^{8}$. Tackett et al., supra note 197 , at $65^{6}$.

259. See Anand et al., supra note 247, at 11 tbl.1.

26o. See generally Leandra Lederman, The Interplay Between Norms and Enforcement in Tax Compliance, 64 OHIO ST. L.J. 1453 (2003) [hereinafter Lederman, Interplay] (synthesizing the experimental and empirical evidence and arguing tax enforcement buttresses tax compliance norms and can help tip a noncompliance norm in a community to a compliance norm); see also Lederman, supra note 2, at 653 (arguing that "[a] 2009 study of individuals from the neighboring countries of Botswana and South Africa supports the idea that enforcement efforts are more effective where compliance norms are stronger" (footnote omitted) (citing Ronald G. Cummings, Jorge Martinez-Vazquez, Michael McKee \& Benno Torgler, Tax Morale Affects Tax Compliance: Evidence from Surveys and an Artefactual Field Experiment, 7o J. ECON. BEHAV. \& ORG. 447, 447 $(2009)))$.

261. James Alm \& Jorge Martinez-Vazquez, Institutions, Paradigms, and Tax Evasion in Developing and Transition Countries, in Public FinANCE IN DEveloping AND Transitional COuNTRIES 146, $15^{1}$ (Jorge Martinez-Vazquez \& James Alm eds., 2003) (adding that "[s]uch an outcome is common in many countries, such as the Philippines and Italy").

262. See supra text accompanying notes 1-3.

263. See, e.g., Cummings et al., supra note 260 , at 449 ("[E]xtreme . . risk aversion would be required to explain observed . . . compliance [under the deterrence model]. Other factors must be at work."); Richard Lavoie, Flying Above the Law and Below the Radar: Instilling a Taxpaying Ethos in Those Playing by Their Own Rules, 29 PACE L. REV. 637, 642 (2009) ("Because the deterrence model fails to accurately predict tax evasion levels, other forces must be influencing citizens to comply despite the apparently overwhelming economic utility of cheating."); Eric A. Posner, Law and Social Norms: The Case of Tax Compliance, 86 VA. L. REV. 1781, 1782 (2000) (stating that "[a] widespread view among tax scholars holds that law enforcement does not explain why people pay 
is no reason that deterrence and behavioral factors cannot both positively influence tax compliance. Studies generally find that audits and audit threats have a strong positive effect on compliance, ${ }^{264}$ and that behavioral factors such as norms appeals ${ }^{265}$ have at least some positive effect. ${ }^{266}$ This Part argues

taxes" and advocating for a signaling model of tax compliance); Alex Raskolnikov, Crime and Punishment in Taxation: Deceit, Deterrence, and the Self-Adjusting Penalty, 106 Colum. L. REV. 569, 577-79 (2006) ("If the economic analysis does not fully explain tax compliance, what does? Perhaps, looking at human beings as more than mere 'rational rats' may provide the answer. ... Clearly, more experimental results would be helpful in resolving theoretical debates. In the meantime, the best one can do ... is to explicitly ground any proposal aimed at improving tax administration in one of the competing views about taxpayer behavior." (footnotes omitted)).

264. See, e.g., Liucija Birskyte, Effects of Tax Auditing: Does the Deterrent Deter?, 8 RsCH. J. ECON., BUS. \& ICT, no. 2, 2013 , at 1, 5 (finding that "[a] $1 \%$ increase in federal audit rate, on the average, increases individual income state tax collected per return by 1.74 dollars, holding other variables constant" (emphasis added)); Henrik Jacobsen Kleven, Martin B. Knudsen, Claus Thustrup Kreiner, Søren Pedersen \& Emmanuel Saez, Unwilling or Unable to Cheat? Evidence from a Tax Audit Experiment in Denmark, 79 ECONOMETRICA 651,689 (2011) (concluding in part that "[f] or selfreported income, ... tax evasion is substantial and responds negatively to an increase in the perceived probability of detection coming from either a prior audit or a threat-of-audit letter"); cf. OfF. OF MGMT. \& Budget, APPENDix, Budget of THE UNITED STATES GOVERNMENT, FisCAL YEAR 2016, at 1035 (2015), https://www.govinfo.gov/content/pkg/BUDGET-2016-APP/pdf/ BUDGET-2016-APP.pdf [https://perma.cc/SA3D-HYMV] (referring to "the indirect revenue effect of the deterrence value of [IRS tax] enforcement investments, which is estimated to be at least three times the direct revenue impact").

Studies generally find that penalties have a positive but smaller effect than audits on tax payments. See Lederman, supra note 2, at 66o-66 (summarizing studies).

265. See, e.g., Lucia Del Carpio, Are the Neighbors Cheating? Evidence from a Social Norm Experiment on Property Taxes in Peru 31 (Nov. 12, 2013) (unpublished paper), https:// www.econ.ku.dk/Kalender/seminarer/18022014/Carpio.Are_the_neighbors_cheating_Nov1 2.pdf [https://perma.cc/ENR6-8HLA] ("Disclosing the true rate of (previous) compliance has a large significant positive impact on compliance ( $20 \%$ relative to the control group). The payment reminder, however, can explain almost half of this increase.”); STEPHEN COLEMAN, MINN. DEP'T of Revenue, The Minnesota Income Tax Compliance Experiment: State Tax Results 18 (1996), https://mpra.ub.uni-muenchen.de/4827/1/MPRA_paper_4827.pdf [https://perma.cc/ $\mathrm{E}_{7 \mathrm{AL}-6 \mathrm{PAJ}}$ ] (finding in a study of Minnesota taxpayers that "Letter 2 [the norms letter] ... had a moderately significant effect on the entire sample and a stronger effect within a large subgroup of taxpayers"); Michael Wenzel, Misperceptions of Social Norms About Tax Compliance: From Theory to Intervention, 26 J. ECON. PSYCH. 862, 877-78 (2005) ("When taxpayers were informed about the inconsistency between their own tax ethics and those attributed to other people, they claimed fewer non-WRE [work-related expense] deductions compared to taxpayers who had not received that information. However, no effect emerged for WRE claims, even though survey questions and feedback intervention explicitly referred to these.”). But cf. Marsha Blumenthal, Charles Christian \& Joel Slemrod, Do Normative Appeals Affect Tax Compliance? Evidence from a Controlled Experiment in Minnesota, 54 NAT'L TAX J. 125,132 (2001) (describing "Letter2 (Join the Compliant Majority)" and not finding a statistically significant effect in a study using the same Minnesota data as Stephen Coleman).

266. Other behavioral factors may have an effect, as well. For example, there are several studies examining the effect of procedural fairness or procedural justice on tax compliance. See, e.g., Martina Hartner, Silvia Rechberger, Erich Kirchler \& Alfred Schabmann, Procedural Fairness and Tax Compliance, $3^{8}$ ECON. ANALYSIS \& POL'Y 1 137, 149-50 (2008) ("Overall, and despite the limitations of the findings in terms of extrapolatibility, the analysis shows a clear direct effect of procedural justice on motivational postures with all three samples.”); Kristina Murphy, Procedural Justice and Tax Compliance, 38 AUSTL. J. SOC. IssuES 379, 384 (2003) (studying "why the majority of [certain tax] scheme investors reacted in such a negative way to the ATO's [Australian Taxation Office] handling of the issue"); Michael Wenzel, The Impact of Outcome Orientation and 
that the fraud triangle's framework is a useful lens for bringing together multiple theories on tax compliance motivations.

\section{A. THE DETERRENCE MODEL AND THE FRAUD TRIANGLE}

As is well known in the tax compliance literature, under the deterrence model of tax compliance, the taxpayer compares the cost of compliance with the expected cost of evasion.

For example, a taxpayer who omits from income an amount resulting in understated tax of $\$ 1$ ooo and who faces a $1 \%$ chance of audit that will detect the evasion and a $20 \%$ penalty in addition to the tax if detected (\$1200 in total), faces an "expected" (probabilistic) cost of $\$ 12 .{ }^{267}$

The model thus captures the probabilistic aspect of enforcement. This example also uses realistic audit and penalty rates for the U.S. federal income tax system. ${ }^{268}$ In the example, the expected cost of cheating of only $\$ 12$ contrasts with the much higher cost of $\$ 1$, ooo if the taxpayer fully complies with the tax laws with respect to the income in question. This provides a financial incentive to cheat. ${ }^{269}$

\section{The Fraud Triangle's "Incentive or Pressure" Prong}

Recall that the first prong of the fraud triangle is incentive or pressure (usually financial in nature)..$^{27}$ Incentive is a key component of deterrence, ${ }^{271}$

Justice Concerns on Tax Compliance: The Role of Taxpayers' Identity, 87 J. APPLIED PsYCH. 629, 639 (2002) (finding that " $[\mathrm{n}]$ oncompliance with regard to income reporting and tax minimization was exclusively predicted by self-interest variables, whereas noncompliance in reporting of extra income as well as deduction claims was additionally influenced by identification and, interacting with identification, perceptions of justice").

267. Lederman, supra note 2 , at $64^{2}$ (footnote omitted). The math is as follows: $0.01 *(\$ 1,000+[0.2 * \$ 1,000])$.

268. The standard U.S. federal tax penalty is 20 percent of the understated tax, on top of the tax due. I.R.C. $\$ 6662(\mathrm{a})-(\mathrm{b})$ (2018) (imposing a 20 percent penalty for such things as negligence or substantial understatement of tax); $c f$. $i d$. $\S 666_{3}$ (a) ("If any part of any underpayment of tax required to be shown on a return is due to fraud, there shall be added to the tax an amount equal to 75 percent of the portion of the underpayment which is attributable to fraud.”). Currently, the IRS reports audit rates for U.S. individuals and corporations of less than one percent. See IRS, INTERNAL REVENUE SERVICE DATA BOOK, 2019, at 35 tbl.17a (2020), https://www.irs.gov/pub/irs-pdf/p55b.pdf [https://perma.cc/R9CE-4RJM] (stating that 0.15 percent of individual tax returns and 0.06 percent of corporate returns were examined by the IRS for fiscal year 2018). Those rates have been declining over time. See id. at $35^{-43}$ tbl.1 7 a. For example, in 2010 , those rates were 1.01 percent and 1.55 percent, respectively. Id. at 43 tbl.1 $7 \mathrm{a}$.

269. See Lederman, supra note 2, at 644 ("Given these low levels of audit rates and penalties, it seems that a rational wealth-maximizing taxpayer should cheat whenever possible.”).

270. See supra text accompanying note 10.

271. Matthew McCaffrey, Incentives and the Economic Point of View: The Case of Popular Economics, 1 REV. SOC. \& ECON. ISSUES, Summer 2014, at 71, 72 ("[T] he incentive theory inspired by Gary Becker and many Chicago economists ... introduced incentive thinking to behavior typically considered outside the scope of economics, creating fields such as the economics of ... crime and punishment ...."). 
so it fits very well with the economic deterrence model. For example, Brian Erard and Jonathan Feinstein start an article on tax compliance with the statement:

In economic models of tax compliance it has traditionally been assumed that taxpayer reporting behavior is driven primarily by the incentives of the tax system. According to this framework, taxpayers choose how much income to report on their tax returns by solving a standard expected utility-maximization problem that trades off the tax savings from underreporting true income against the risks of audit and penalties for detected non-compliance. ${ }^{272}$

In other words, as in the calculation above, ${ }^{273}$ the possibility of paying less to the government provides a financial incentive to evade one's tax obligations. ${ }^{274}$ That incentive exists regardless of whether a taxpayer also faces financial pressures, although such pressures could increase the impulse to cheat. ${ }^{275}$

From the perspective of the deterrence model, a context in which the expected value of cheating is higher than the expected value of complying fosters evasion. ${ }^{276}$ Mathematically, the incentive facing the taxpayer could be flipped to an incentive to comply by raising the expected cost of evasion to exceed the cost of compliance. For example, if the cost of compliance is $\$ 1, \mathrm{ooo}$, as in the example, but the expected cost of evasion were $\$ 1,100-$ due to the likelihood of detection and the magnitude of the penalty imposed on those caught cheating - the taxpayer's incentive would be to comply.277 As this example shows, the first prong of the fraud triangle connects well with economic analysis of the tax compliance decision.

272. Brian Erard \& Jonathan S. Feinstein, Honesty and Evasion in the Tax Compliance Game, 25 RAND J. ECON. 1, 1 (1994) (emphasis added). The article advances the importance to tax policy of honest taxpayers who do not succumb to the financial incentive to cheat. Id. at 2.

273. See supra text accompanying notes $267-68$.

274. See supra text accompanying note 228; cf. Robert R. Oliva \& Roger W. Dorsey, From Colony to Home Concrete \& Supply: Is Unrecovered Basis "Gross Income"? Extending the Statute of Limitations on Assessment from Three Years to Six Years, TAXES, Feb. 2013, at 49, 6o (2013) (applying the fraud triangle to the context of a sale of property, and stating, "all of us, as taxpayers, are motivated to maximize after-tax wealth").

275. See supra Section IV.A.

276. Stephen W. Mazza, Taxpayer Privacy and Tax Compliance, $5^{1}$ U. KAN. L. REV. 1065, 1066 (2003) ("[T]he basic economic model of tax evasion, developed by Allingham and Sandmo .... predicts that a taxpayer will evade taxes when the expected gains from evasion, determined in part by the tax rate, exceed the expected value of the punishment, determined by the probability of detection and the resulting penalty if caught." (footnote omitted)).

277. Although, in theory, the penalty could be made large enough that a small likelihood of detection - such as the one percent audit rate in the example-would provide an incentive to comply, studies have found that a greater likelihood of detection is much more effective at spurring compliance than higher penalties are. See Lederman, supra note 2, at 66o-66 (summarizing studies). 


\section{The Fraud Triangle's "Opportunity" Prong}

Under the basic economic model, at the realistic audit and penalty levels reflected in the example above, ${ }^{278}$ evasion appears much less costly than compliance, implying that the taxpayer would always choose evasion. Thus, the deterrence model would seem to predict zero compliance. Yet, we observe positive and even high compliance rates in the real world. For example, the IRS estimates an overall voluntary compliance rate of 81.7 percent with legalsource income. ${ }^{279}$ Economists framed this as the tax compliance "puzzle," 280 and numerous scholars have stated based on this superficial comparison that the deterrence model is incorrect. ${ }^{281}$

Yet, this purported compliance "puzzle" ignores (among other things) ${ }^{282}$ the issue of opportunity to evade. ${ }^{283}$ That is, simply comparing (relatively) low

278. See supra text accompanying notes $267-68$.

279. IRS, TAX GAP ESTIMATES FOR TAX YEARS 2008-2010, supra note 234, at 6-7.

28o. See, e.g., James Alm, Isabel Sanchez \& Ana de Juan, Economic and Noneconomic Factors in Tax Compliance, 48 KYKLOS 3, 3 (1995) ("[T] he puzzle of tax compliance is not so much 'Why is there so much cheating?' Instead, the real puzzle is 'Why is there so little cheating?'” (emphasis added)); Lars P. Feld \& Bruno S. Frey, Tax Compliance as the Result of a Psychological Tax Contract: The Role of Incentives and Responsive Regulation, 29 LAW \& POL'Y 102, 102 (2007) ("The puzzle of the economic theory of tax compliance is why people pay taxes."); J.T. Manhire, There Is No Spoon: Reconsidering the Tax Compliance Puzzle, 17 FLA. TAx REV. 623, 63o (2015) ("[H] ow does one explain the relatively high voluntary compliance rate given the relatively low audit rate in the United States? This apparent difficulty is sometimes referred to as the 'tax compliance puzzle."); Benno Torgler \& Friedrich Schneider, The Impact of Tax Morale and Institutional Quality on the Shadow Economy, 3o J. ECON. PSYCH. 228, 230 (2009) (explaining "in many countries, the level of deterrence is too low to explain the high degree of tax compliance" and referring to the "puzzle of tax compliance").

281. See, e.g., Frey, supra note 3, at 389 ("There is compelling evidence that the deterrence model, and therewith tax policy based on deterrence, is at best incomplete, and may even be wrong.”); MARC LEROY, L'IMPÔT, L'ÉTAT ET LA SOCIÉTÉ: LA SOCIOLOGIE FISCALE DE LA DÉMOCRATIE INTERVENTIONNISTE $24^{1}$ (2010) ("Concernant le risque du contrôle fiscal, un fait important est que la fréquence moyenne de vérifications est en générale faible, et donc que le respect des obligations déclaratives devrait être plus faible qu'il n'est: cette observation contredit l'approche par la maximisation de l'utilité." (meaning: "With respect to tax enforcement, an important fact is that the average audit rate generally is low, and so voluntary tax compliance should be lower than it actually is; this observation contradicts the utility-maximization approach.") (translation by the author)); J. Manhire, Toward a Perspective-Dependent Theory of Audit Probability for Tax Compliance Models, 33 VA. TAX REV. 629, 629 (2014) ("The classic deterrence theory model of income tax evasion first articulated in 1972 has met significant criticism because it does not comport with the observed rate of tax compliance."); Posner, supra note $26_{3}$, at 1782 ("A widespread view among tax scholars holds that law enforcement does not explain why people pay taxes.").

282. See Lederman, supra note 2 , at $65^{\mathrm{O}-55}$ (summarizing factors missing from the basic deterrence model, including criminal penalties and the hassle of undergoing an audit).

283. See, e.g., Kleven et al., supra note 264 , at 653 (" $[\mathrm{O}]$ ur findings suggest that tax evasion is low, not because taxpayers are unwilling to cheat, but because they are unable to cheat successfully due to the widespread use of third-party reporting."); Lederman, supra note 2, at 646 ("While there is certainly room for civic commitments and respect for the law as explanations for some compliance, the lack of opportunity for tax evasion ... explains much tax compliance and is consistent with the deterrence model."); Lederman, Statutory Speed Bumps, supra note 236, at 697 ("An essential missing piece of this seeming puzzle is that the federal income tax law benefits from structural mechanisms that constrain payment with respect to the major sources of income 
audit rates and penalties with (relatively) high compliance rates assumes that taxpayers have an open opportunity to cheat with respect to all items on the tax return-but that is not the case. There are at least two important ways in which the government restricts the opportunity to evade taxes. One involves a "structural system" and the other involves monitoring that is not included in audit statistics.

A structural system is a built-in constraint that channels behavior, in contrast with rules that require monitoring of compliance. For example, a road can be structured to reduce speeding, such as by installing a speed bump. ${ }^{28}$ The speed bump is a form of structural deterrent. It contrasts with mere speed limits and posted signs, which do not structurally foster compliant behavior.

Because structural systems impose constraints on behavior, they should require much less monitoring for compliance than does a law or rule without a constraining structure. In the tax law, withholding serves as a structural system. ${ }^{285}$ This system involves a third party (typically someone who is at arm's length from the taxpayer), rather than a physical feature such as a speed bump, but it still helps to constrain the taxpayer's compliance. The IRS estimates timely and voluntary tax payment with respect to income subject to withholding at 99 percent. ${ }^{286}$

With respect to monitoring, some monitoring of taxpayers' activities is not included in audit statistics. ${ }^{287}$ That includes some IRS contacts with the

for many people, including wages and salaries.”); Joel Slemrod, Cheating Ourselves: The Economics of Tax Evasion, J. ECON. PERSPS., Winter 2007, at 25, 37 ("Line item by line item, there is a clear positive correlation between the rate of compliance and the presence of enforcement mechanisms such as information reports and employer withholding.").

284. See Lederman, Statutory Speed Bumps, supra note 236, at 696 ("[I]f the government seeks to reduce speeding in a residential neighborhood, instead of (or in addition to) imposing fines and ticketing speeders, it can construct roads in ways that help reduce speeding, such as making them narrow or winding, or including speed bumps." (footnote omitted)).

285. Id. at 697-98. This structural system involves human beings who could, in theory, collude with the taxpayer. However, there are numerous incentives for the withholding agent to comply rather than colluding with the taxpayer. See Lederman \& Dugan, supra note 233, at 199-202.

286. See supra text accompanying note 238; IRS, TAX GAP ESTIMATES FOR TAX YEARS 2011 -2013 , supra note $23^{8}$, at 14 fig.3.

287. The National Taxpayer Advocate has explained:

The IRS has several . . . types of compliance contacts with taxpayers that it does not consider to be "real" audits. These types of contacts, which I call "unreal" audits, include math error corrections, Automated Underreporter (AUR) (a document matching program), identity and wage verification, and Automated Substitute for Return (ASFR) (a non-filer program).

$\ldots$

In fiscal year $2016 \ldots$, the IRS conducted slightly more than a million "real" audits, resulting in an audit rate of 0.7 percent. However, during the same timeframe, the IRS conducted approximately 8.5 million "unreal" audits. When adding these "unreal" audit numbers to the "real" ones, the IRS's combined coverage rate jumps to over six percent.

Nina E. Olson, NTA Blog: "Real” vs. "Unreal" Audits and Why This Distinction Matters, TAXPAYER ADVOC. SERV. (July 6, 2018), https://taxpayeradvocate.irs.gov/news/nta-blog-real-vs-unrealaudits-and-why-this-distinction-matters [https://perma.cc/Q7PM-PENQ]. 
taxpayer. ${ }^{288}$ It also includes third-party information reporting. Third-party reporting is analogous to a technology such as a speed camera or red-light camera: It informs the government of the individual's behavior, typically while also informing the individual that the government is watching. ${ }^{289} \mathrm{~A}$ taxpayer who receives $\$ 1$, ooo of interest or dividend or salary income generally cannot omit it and face a mere one percent chance of detection because third-party reporting (and possibly withholding) makes the payment transparent to the IRS. "Information returning matching can be viewed as an invisible audit —but it is not counted in audit rate statistics." ${ }^{290}$

The fraud triangle's second factor is perceived opportunity-which, in the tax context, is perceived opportunity to evade. Although IRS matching of information returns with taxpayer returns may not occur 1 oo percent of the time, the taxpayer's perceived opportunity to evade decreases dramatically in the presence of third-party reporting. The IRS estimates timely and voluntary tax payment with respect to income subject to complete third-party information reporting (but not withholding) at a very high rate- 95 percent. ${ }^{21}$ The fraud triangle's focus on perceived opportunity helps highlight the importance of taxpayer perception to tax noncompliance.

In applying the fraud triangle's "opportunity" prong to tax evasion, Tackett et al. provide the following analogy:

Suppose a department store operated on the honor system, in which customers selected merchandise, tallied their bill, and remitted their payment without any supervision other than a 1 percent chance of being audited. Assume further that customers who are caught cheating are almost never prosecuted, but merely have to pay the accurate amount of their purchase along with a modest financial penalty. How long would such a store remain in business? The scenario is analogous to the federal income tax system. ${ }^{292}$

This is an interesting analogy, but it reflects the same trap that scholars who only look at audits and penalties when evaluating the deterrence model fall into: It is apt only for amounts not subject to third-party reporting. Imagine if this hypothetical store also had a department with all of its merchandise in locked cases, where a salesperson had to take the merchandise and an invoice to a cashier to await customer payment. That department would no doubt experience much less nonpayment, just as items subject to third-party information reporting do. ${ }^{293}$ The locked case is a structural system, analogous to withholding, and the accompanying person

\footnotetext{
288. Id.

289. See Lederman, Statutory Speed Bumps, supra note 236 , at 696.

29o. Lederman, Reformed IRS, supra note 209, at 975 .

291. See supra text accompanying note 238; IRS, TAX GAP ESTIMATES FOR TAX YEARS 2011 -2013, supra note 238 , at 11 tbl.2.

292. Tackett et al., supra note 197 , at 656 .

293. See supra text accompanying note 238 .
} 
essentially provides information reporting, reducing the perceived opportunity for malfeasance.

Thus, two of the three fraud triangle factors-incentive or pressure and perceived opportunity-align nicely with the deterrence model of tax compliance. The third factor, rationalization, fits better with behavioral theories of tax compliance, as discussed in the next Section.

\section{B. BEHAVIORAL APPROACHES TO TAX COMPLIANCE AND THE FRAUD TRIANGLE'S “RATIONALIZATION" PRONG}

While deterrence has been shown empirically to positively affect tax compliance, ${ }^{294}$ it is not the only positive influence. Behavioral factors also matter. As a simple example, risk aversion is a behavioral factor that is often discussed in connection with the basic economic model of tax compliance. ${ }^{295}$ Risk aversion increases deterrence under the basic economic model. ${ }^{296}$ This example shows that a behavioral element need not be considered inconsistent with economic modeling of tax compliance.

Thus, considering a prong of the fraud triangle other than the two discussed above in connection with the deterrence model-incentive or pressure and perceived opportunity-does not undermine those two prongs. The fraud triangle's third factor, rationalization, is focused on the psychological aspects of the violation and thus fits well with behavioral theories. This Section focuses on two frequently discussed behavioral theories, social norms and tax morale sourced in trust in government, to show how the rationalization prong of the fraud triangle sheds light on them.

\section{Norms of Compliance or Noncompliance}

Several scholars have studied the effects on tax compliance of normative appeals. ${ }^{297}$ Such appeals generally take the form of a letter from the tax authority touting the community's high level of compliance. ${ }^{29} 8$ As noted

294. See supra note 264 and accompanying text (discussing the effectiveness of audits and audit threats); see also supra text accompanying notes $233^{-41}$ (discussing the role of third-party reporting).

295. See, e.g., Allingham \& Sandmo, supra note 1, at 327 (including risk aversion in original economic model of tax compliance); James Andreoni, Brian Erard \& Jonathan Feinstein, Tax Compliance, 36 J. ECON. LITERATURE 818, 823 (1998) (including taxpayer risk aversion in a basic economic model of compliance).

296. Allingham \& Sandmo, supra note 1, at 329 ("[W] hen actual income varies, the fraction declared increases, stays constant or decreases ... as relative risk aversion is an increasing, constant or decreasing function of income.”).

297. See, e.g., Blumenthal et al., supra note 265, at 129 (describing "Letter2: Join the Compliant Majority"); John Hasseldine, Peggy Hite, Simon James \& Marika Toumi, Persuasive Communications: Tax Compliance Enforcement Strategies for Sole Proprietors, 24 CONTEMP. ACCT. RSCH. 171,178 (2007) (reporting on a study that included in one letter both a norms-based appeal and moral suasion); Wenzel, supra note $26_{5}$, at 871 (surveying taxpayers and reporting survey results in a letter).

298. See, e.g., Blumenthal et al., supra note $26_{5}$, at 129 ("The middle paragraph [of Letter 2] stated that IRS audits show that 'people who file tax returns report correctly and pay voluntarily 93 percent of the income taxes they owe.' It concluded, 'Although some taxpayers owe money 
above, some studies show that appeals to compliance norms may have at least a modest positive effect on tax payments. ${ }^{299}$ Similarly, community norms of noncompliance may foster noncompliance. $3^{300}$

The fraud triangle's rationalization prong focuses on the psychology of the offender. Cressey explained that "rationalization," in the sense in which he used the term, can "refer to a process of finding some logical excuse for questionable behavior tendencies, for thoughts as well as acts, and for decisions to perform an act." ${ }^{\circ 1}$ Thus, rationalization allows the offender to mentally justify his or her actions, so as to minimize cognitive dissonance between a self-image as an honest person and the fraudulent action..$^{02}$

A knowledge of community norms of honesty may make rationalizations of tax evasion less effective. For example, if the taxpayer is credibly told that most community members comply with their tax obligations, that may make it harder for that person to justify evasion on the basis of bandwagon-type rationalizations such as "everyone does it." Similarly, such an information campaign about compliance helps undermine neutralizations $3^{303}$ such as tax cheating is "not really wrong." $3^{\circ} 4$ By contrast, norms of noncompliance may facilitate rationalizations that the violation is not really a crime, or not so bad, or required so as not to be the only chump paying full freight.305 Thus, community norms may hinder or facilitate rationalizations that help a taxpayer justify evasion.

because of minor errors, a small number of taxpayers who deliberately cheat owe the bulk of unpaid taxes."”); Wenzel, supra note $26_{5}$, at 874 (quoting a letter to taxpayers: "These [survey] results indicate that we tend to think most people accept tax cheating and exaggerations in tax deductions. However, the truth is that most people think we should be honest with our tax statements and claim only those deductions that are allowable."); $c f$. Hasseldine et al., supra note 297, at 178 (describing letter combining elements of a normative appeal and moral suasion).

299. See supra note $2_{5}$ and accompanying text.

3oo. See Lederman, Interplay, supra note 260 , at 1470 (noting the possibility that "observing others' noncompliance might change the observer's moral standard so that he or she might feel less guilt in failing to comply").

301. CREsSey, Other PeOPle's MONEY, supra note 16, at 94 (footnotes omitted).

302. See supra notes $4^{8-5} 5^{1}$ and accompanying text.

303. See Sykes \& Matza, supra note 243, at 667 ("[T] he delinquent represents not a radical opposition to law-abiding society but something more like an apologetic failure, often more sinned against than sinning in his own eyes. We call these justifications of deviant behavior techniques of neutralization ...." (emphasis added)).

304. Anand et al., supra note 247, at 12. In the language of Anand, Ashforth, and Joshi, this rationalization is "denial of injury." Id.; see supra note 248 (referring to other recent works that discuss rationalizations).

305. See supra text accompanying notes $25^{8-61}$ (discussing these rationalizations). 
Enforcement may also help foster compliance norms, $3^{06}$ perhaps because it signals that violators are punished. $3^{\circ} 7$ One study's results suggest that enforcement may even be more effective where compliance norms are stronger. $3^{08}$ The fraud triangle framework supports that idea because it is harder to rationalize that one's behavior is not illegal or does not matter to the government if the government is visibly enforcing the law.

\section{Taxpayer Views of Government}

Some taxpayers may use claimed government failures to justify tax noncompliance. $3^{\circ 9}$ For example, they may object to how tax revenues are spent. They may refuse to pay tax, or certain taxes, until government policies change. ${ }^{10}$ In a 1991 article, Kent Smith and Loretta Stalans listed "[t]hree [categories] of people [who] account for the majority of noncompliance with tax laws." ${ }_{11}^{11}$ The category relevant here is "those who willfully engage in tax noncompliance because they perceive that their tax dollars are not being spent appropriately or that government authorities are not treating them or other taxpayers appropriately." ${ }^{12}$

As this may suggest, one way to view the taxpayer/government relationship is as a type of contract. For example, political scientist John T. Scholz has advanced a "contractarian" theory of tax compliance under which taxpayers factor in the government's provision of public goods.313 European economists Lars Feld and Bruno Frey have referred to a "psychological tax

3o6. See Del Carpio, supra note $26_{5}$, at 21 (finding that "[a]fter the municipal enforcement policy begins, ... the effect of the norms treatment relative to the payment reminder increases almost two-fold . . . , and the difference between the two is marginally significant $(p=15 \%)$ " and arguing that this "points to an interesting complementarity between the norms treatment and the standard enforcement policy").

307. See John T. Scholz, Contractual Compliance and the Federal Income Tax System, 13 WASH. U. J.L. \& POL'Y 139, 192 (2003) (arguing that, under his contractarian model of tax compliance, "the critical function of the state's tax enforcement power is to assure adaptive contractarians that other citizens will meet their contractual obligations, assuring the adaptive contractarian that he or she is not foolish in meeting these same obligations"); see also Lederman, Interplay, supra note 260 , at 1499 (arguing, based on experimental evidence, that "[e]nforcement may therefore have the effect of deterring some people and increasing the robustness of a compliance norm for others by minimizing their exposure to tax evasion").

308. See Cummings et al., supra note 26o, at 448 ("[W] hile compliance does increase with enforcement effort, the effect is less in the country for which governance is less good."); Lederman, supra note 2, at $65^{8-59}$ (arguing that the study's results show greater normative commitments to tax compliance in Botswana than the compared country, South Africa).

309. See supra text accompanying note 257.

310. See James Alm, Betty R. Jackson \& Michael McKee, Fiscal Exchange, Collective Decision Institutions, and Tax Compliance, 22 J. ECON. BEHAV. \& ORG. $28_{5}, 28_{5}$ (1993).

311. Kent W. Smith \& Loretta J. Stalans, Encouraging Tax Compliance with Positive Incentives: A Conceptual Framework and Research Directions, 13 LAW \& POL'Y 35, 36 (1991).

312. Id. The other two categories Smith and Stalans identified were (1) subcultures where tax cheating is the norm, and (2) those making careless errors. Id. The first category relates to the norms discussion above. See supra Section V.B.1. The latter category does not involve fraud, the focus of this Article.

313. See Scholz, supra note 307, at 139-40. 
contract" between taxpayers and the government.314 Feld and Frey argued that "a steady reduction in tax compliance need not only be interpreted as a violation of the law, but also as taxpayers' discontent with what they receive for their taxes." 315

Others have different views. For example, Joshua Rosenberg has argued that the payment of taxes and the receipt of benefits are not very linked in most taxpayers' minds, due to "the separation of the burdens of tax from the benefits of government." 316 Moreover,

the benefits of taxes (that is, the receipt of government services) seem both small and unrelated to our actual tax payments. As the benefits of tax fade from consciousness, and as their burdens grow in prominence, we begin to perceive the taxes themselves as little more than undeserved and unduly painful punishments. ${ }^{317}$

Studies generally have not found a significant effect on tax payments of letters sent to taxpayers that focus on the public goods the government provides..$^{318}$

While a decline in tax compliance could have many causes, including a reduction in the audit rate,319 taxpayer claims that they are protesting government wrongs could seem to suggest that "good government" measures would foster compliance. Feld and Frey argue that "[t]he[] bonds between taxpayers and the state represent the core of individual tax morale, and thus positively affect tax compliance." 320 Appropriate treatment of the citizenry should certainly be a government priority, but whether it results in increased

314. Feld \& Frey, supra note 280, at 106 ("In the psychological tax contract, punishment still plays a role in order to provide deterrence. But the satisfaction of taxpayers with what they get from the other contract party, that is, the government, mainly influences their tax morale.").

315. Id. at 107 .

316. Joshua D. Rosenberg, The Psychology of Taxes: Why They Drive Us Crazy, and How We Can Make Them Sane, 16 VA. TAX REV. 155, 171 (1996).

317. Id.

318. See, e.g., Barak Ariel, Deterrence and Moral Persuasion Effects on Corporate Tax Compliance: Findings from a Randomized Controlled Trial, $5^{\circ}$ CRIMINOLOGY 27, 43-44, $5^{8}$ (2012) (finding that a letter to Israeli corporations explaining "how tax dollars were allocated," providing "[r] easons for paying taxes," and highlighting the societal harm from not paying, resulted in a small but statistically significant effect in the direction of noncompliance with a Value Added Tax (VAT)); Blumenthal et al., supra note $26_{5}$, at 128-32 (finding no statistically significant effects of a "Support Valuable Services" letter); Benno Torgler, Moral Suasion: An Alternative Tax Policy Strategy? Evidence from a Controlled Field Experiment in Switzerland, 5 ECON. GOVERNANCE 235, 240, 249-5 (2004) (finding an insignificant effect on timely filing and payment in Trimbach, Switzerland, of a letter stating, "[i]f the taxpayers did not contribute their share, our commune with its 6226 inhabitants would suffer greatly. With your taxes you help keep Trimbach attractive for its inhabitants.”). But cf. Michael Chirico, Robert P. Inman, Charles Loeffler, John MacDonald \& Holger Sieg, An Experimental Evaluation of Notification Strategies to Increase Property Tax Compliance: Free-Riding in the City of Brotherly Love, 30 TAX POL'Y \& ECON. 1 29, 146-47 \& tbl.5 (2016) (finding that a letter describing public services had a statistically significant effect at $\mathrm{p}<.05$ on the subgroup of single-property owners).

319. See Lederman, supra note 2, at 693 (concluding, based on a synthesis of studies, that "at low audit rates such as those in the United States, the evidence suggests that increasing the audit rate would increase overall tax compliance" (emphasis omitted)).

320. Feld \& Frey, supra note 280 , at 103 . 
tax compliance is an empirical question. Different reforms may have different effects. For example, previous work found that there is some evidence that procedural fairness on the part of the tax collector increases tax payments, ${ }^{321}$ but that there was no evidence that increased service by the tax collector did So. 322

Frey and other scholars have argued that "tax morale" is central to tax compliance. $3^{23}$ This term is generally used to refer to all intrinsic motivations to pay taxes. $3^{24}$ It contrasts with deterrence, which involves the extrinsic motivators of audits and penalties. ${ }^{25}$ Frey has pointed to trust in government as the principal source of tax morale, arguing that:

Tax morale must be put in the general context of the relationship between citizen and the state: At the one extreme, there are exploitative governments ruling their people in an authoritarian or even dictatorial way.... At the other extreme, there are participatory governments in which the taxpayers as citizens can themselves determine for what purposes the revenues should be used. $3^{26}$

While deterrence and behavioral theories of tax compliance can coexist,327 some have argued that deterrence, with its focus on extrinsic motivators, may reduce voluntary inclinations to comply, even to the point of increasing noncompliance. ${ }^{28}$ In this vein, Frey has argued in part that

321. See Lederman, Reformed IRS, supra note 209, at 996-1004 (synthesizing then-existing studies); see sources cited supra note 266 (citing additional studies).

322. See Lederman, Reformed IRS, supra note 209, at 992-96 (synthesizing then-existing studies).

323. See supra note 3 and accompanying text; see infra text accompanying note 326 . Frey's claims are strong and are countered in Lederman, supra note 2, at $642-55$.

324. See, e.g., Lars P. Feld \& Bruno S. Frey, Trust Breeds Trust: How Taxpayers Are Treated, 3 ECON. GOVERNANCE 87, 88 (2002) ("[T] he existence of an intrinsic motivation to pay taxes ... has sometimes been called "tax morale."); Frey, supra note 3 , at 389 (arguing "that intrinsic motivation in the form of 'tax morale' is of substantial importance in explaining tax paying behaviour").

325. See Torgler, supra note 318 , at 236 ("When monitoring and penalties for noncompliance are intensified, individuals notice that extrinsic motivation has increased ....”).

326. Frey, supra note 3, at 389-9o (emphasis omitted); see also Bruno S. Frey, Punishment — and Beyond, 5 CONTEMP. ECON. 9o, 92 (2011) [hereinafter Frey, Punishment_and Beyond] ("An unfair, inconsiderate way of treating taxpayers-punishing honest taxpayers by error-tends to undermine this tax morale.”); Bruno S. Frey \& Benno Torgler, Tax Morale and Conditional Cooperation, 35 J. COMPAR. ECON. 136, 144 (2007) ("If taxpayers think they are in a better position to monitor and control politicians, their willingness to cooperate and pay taxes increases. Therefore, a higher degree of satisfaction with a country's democratic institution should lead to higher tax morale."); Feld \& Frey, supra note 280, at 103 ("For that contract to be upheld, incentives such as rewards or punishment need to be provided, but loyalties and emotional ties that go well beyond transactional exchanges must be considered as well. These bonds between taxpayers and the state represent the core of individual tax morale, and thus positively affect tax compliance.").

327. See supra notes 262-66 and accompanying text; see supra text accompanying notes 294-96.

328. See, e.g., Feld \& Frey, supra note 280, at 104 ("Positive (rewards) or negative incentives (deterrence) play a role, but it cannot be taken for granted that they induce tax compliance 
"deterrence imposed by the tax authority may crowd out individuals' intrinsic willingness to conform to tax laws." 329 Similarly, Feld and Frey argued that "[t]wo opposite cases of treating taxpayers can be distinguished: (1) respectful treatment supporting, and possibly raising, tax morale; and (2) authoritarian treatment undermining tax morale." $33^{\circ}$ However, there is little evidence that deterrence has a crowding-out effect that reduces voluntary compliance. ${ }^{33^{1}}$ Instead, there is strong evidence that deterrence, particularly the threat of audit, is very effective at increasing tax payments. $33^{2}$

The lens of the fraud triangle suggests that a view that the government or tax system is unjust or inequitable may be part of the rationalization prong for some people. That is, it may allow people to justify not complying with tax obligations. Joshua Rosenberg has made an argument along these lines:

At least a part of the reason we do not comply more fully with the tax laws is that we believe either taxes specifically, or government in general, is unfair. Also true, however, is exactly the opposite: an important reason we believe tax laws are unfair is that we do not comply more fully with those laws. 333

Rosenberg explains that tax evaders try to avoid the uncomfortable cognitive dissonance that would arise from thinking of oneself as both a lawabiding citizen and as stealing from the government: "In order to allow themselves to maintain a positive sense of self, the 'rational' part of their minds develops an understanding of what they are doing and why they are doing it that allows them to perceive their tax evasion as consistent with being a good, honest citizen." 334 That "understanding" could take the form of a rationalization formulated any number of ways:

Whether this rationalization takes the form of "knowing" that the tax system is unfair, or "knowing" that the government is bad and misguided, is less important than the fact that, regardless of how individuals explain their tax evasion behavior to themselves and others, that explanation is likely to be some ex post rationalization

\footnotetext{
because they may also crowd out tax morale."); Frey, Punishment-and Beyond, supra note 326, at 92 "The net effect of using punishment in an effort to establish legal behavior is counterproductive if the relative price effect of the punishment is smaller than the crowding-out effect."); $c f$. Frey \& Feld, supra note 280 , at 107 ("The feeling of being controlled in a negative way, and being suspected of tax cheating, tends to crowd out the intrinsic motivation to act as an honorable taxpayer and, as a consequence, tax morale will fall.”).

329. Frey, supra note 3, at 391 (emphasis omitted).

330. Feld \& Frey, supra note 280 , at 107.

331. See Lederman, supra note 2, at $655^{-62}$ (synthesizing studies and reaching this conclusion).

332. See supra note 264 (citing sources).

333. Rosenberg, supra note 316, at 199 (emphasis added) (footnote omitted). He adds, "It is doubtful that anyone would ever consciously acknowledge that she thinks taxes are unfair because (rather than so) she cheats on her own taxes, but an individual's lack of awareness of such a reverse-intuitive causal link does not mean that no such link exists." Id.
}

334. Id. at 200-O 1 . 
rather than some guiding vision that motivates the behavior of tax evasion. 335

If Rosenberg is right that, at least for some taxpayers, claimed inequitable behavior by the government is simply a rationalization for evading taxes, better behavior by the government likely would not forestall such evasion. Without an easy scapegoat, evasion might be harder to justify, but some taxpayers might find an alternate rationalization, such as "everyone is doing it" or "they'll never miss the money." Better government behavior also likely would not affect committed evaders. ${ }^{36}$ In terms of the fraud triangle, these may be the people who auditing standards describe as "possess[ing] an attitude, character, or set of ethical values that allow them knowingly and intentionally to commit a dishonest act." 337

The normative implication of this analysis is that it does not make sense to make good-government measures the sole or principal means of attempting to improve tax compliance. Certainly the government should treat people fairly as a matter of principle. Procedural justice may foster tax compliance, as well. $3^{8}{ }^{8}$ However, given taxpayers' financial incentive to pocket tax dollars and the presence of evasion opportunities, the government should not only treat taxpayers fairly, it should also recognize the importance of both structural constraints on evasion and enforcement. Such an approach accords not just with intuition but also with the theoretical framework provided by the fraud triangle. Empirically, limiting the opportunity to evade and increasing the likelihood that evasion will be detected have very positive effects on tax compliance. 339

\section{CONCLUSION}

There is a significant literature on the fraud triangle, particularly in accounting journals. The AICPA also adopted a fraud triangle-based approach in what was then called SAS No. 99, "Consideration of Fraud in a Financial Statement Audit." Some scholars have criticized the fraud triangle as having been inappropriately extended beyond Donald Cressey's initial focus on embezzlers and similar trust violators. It is true that the fraud triangle has evolved over the years, and that, perhaps due to its origin in offender-

335. Id. at 201.

336. Taxpayers may be conceptualized in three main categories: those who are always honest, those who will always try to cheat, and a vast majority whose behavior can be influenced. See Jon S. Davis, Gary Hecht \& Jon D. Perkins, Social Behaviors, Enforcement, and Tax Compliance Dynamics, ACCT. REV., Jan. 2003, at 39, 40 (referring to "honest taxpayers, susceptible taxpayers, and evaders"); cf. Susan C. Morse, Tax Compliance and Norm Formation Under High-Penalty Regimes, 44 CONN. L. REV. 675, 694 (2012) (referring to "determined evaders").

337. Codification of ACct. StAndards \& Procs., Clarified Statements on Auditing Standards, AU-C § 240.A1 (AM. INST. OF CERTIFIED PUB. ACCTS. 2020); ISA 240, supra note 10 , Il A1.

338. See supra text accompanying notes $321-27$.

339. See supra text accompanying notes 238-39 (reporting IRS voluntary compliance estimates, which increase as the IRS receives more information about the transaction); see supra note 264 and accompanying text (citing research on the effectiveness of audits at decreasing tax evasion). 
focused work, it does not focus much on society's role in crime. However, Cressey's factors were not simply adopted wholesale by the AICPA. Work by Steve Albrecht, the Treadway Commission, and others appears to have informed the development of the slightly different factors that are included in U.S. and international auditing standards.

Although the fraud triangle has been well studied, it has largely been overlooked by tax law professors and only rarely applied to tax evasion. Yet, it provides a useful lens when considering the tax evasion decision from an offender perspective. Most notably, the fraud triangle supports the idea that perceived opportunity is a critical-though not the only-factor in tax evasion. The fraud triangle also supports the importance of the deterrence model while still recognizing the importance of behavioral factors on the tax evasion decision.

Generally speaking, the triangle's first two factors-incentive or pressure and perceived opportunity-may be thought of as in line with the deterrence model, while the third factor-rationalization-accords with behavioral theories of compliance. While increasing compliance norms may help limit convenient rationalizations for cheating (and likely more so than goodgovernment measures) structural systems constrain the opportunity to evade. In addition, enforcement actions reduce the incentive and opportunity to cheat, while buttressing compliance norms. The fraud triangle thus provides a useful frame for showing how traditional economic and behavioral theories can work together. The usefulness of the fraud triangle to the understanding of tax evasion also underscores the value of accounting literature and criminology to the study of tax compliance and evasion. 